\title{
LANDLESSNESS, WAR, AND DISPLACEMENT IN LITERATURES OF MINDANAO AND SULU
}

\author{
Sherwin Mendoza \\ De Anza College, Cupertino, CA \\ mendozasherwin@deanza.edu
}

\begin{abstract}
This monograph attempts to clarify the relationships of Filipino Americans to the diaspora of Christian settler colonists in Mindanao with the hope of facilitating solidarity between Filipino Americans and the peoples of Mindanao and Sulu. It begins with a consideration of Carlos Bulosan, perhaps the most prominent figure within the discipline of Filipino American Studies, in terms of the brief appearance of Mindanao in America is in the Heart. The bulk of the monograph, however, is centered on literatures of the Southern Philippines, a region that is often overlooked within the discipline of Filipino American Studies, and in particular it examines the historical evolution of landlessness, displacement, and war in the Southern Philippines through the close reading of texts produced there. The first text is "Blue Blood of the Big Astana," a story from the Commonwealth period of US-Philippine history, written by Ibrahim Jubaira, the mostrecognized Muslim writer in English from the Philippines. Jubaira's story is notable for its depiction of the persistence of ideas concerning land tenure, status, and kinship from a time just prior to US colonial rule within a context determined by the increasing inroads of merchant capitalism fostered by the US colonial state. However, Jubaira's story is very partial when contextualized in terms of debates concerning the fate of Mindanao and Sulu during the years preceding the formal independence of the Philippines. The monograph then moves to the near-present to consider a story by the Maranao writer Loren Hallilah I. Lao, "The Trip to a Forbidden Land," as a plea for peace that is constrained by the middle-class setting of the story. Finally, the emphasis shifts to a set of oral histories collected in the volume Land Tenure Stories in Central Mindanao. The shift to this set of texts corrects an urban and middle-class bias in the stories of Jubaira and Lao that would prevent Filipino American readers from understanding the concerns of Muslims and indigenous peoples and the causes of conflicts in the Southern Philippines. The stories of a specific conflict over land told by Muslims and Manobos in Land Tenure Stories highlight the importance of land as a necessary part of the livelihoods of many of the indigenous, Muslim, and Christian people of Mindanao and the ways in which landlessness and the lack of livelihoods are causes of conflicts in the Southern Philippines.
\end{abstract}




\section{Keywords}

Filipino American Literature, Filipino diaspora, internally displaced persons, landlessness, Muslim Filipino Literature, Philippine Literature in English

\section{About the Author}

Sherwin Mendoza recently received a Ph.D. in World Literature and Cultural Studies from the University of California, Santa Cruz, with a dissertation on the influence of the movement for national democracy in the Philippines on works by Mila Aguilar, Linda Ty-Casper, Jessica Hagedorn, and Ninotchka Rosca. His Ilocano maternal grandparents, who were schoolteachers, were among the Christian settlers who moved to the province of Lanao just after it was drawn up by the US colonial administration early in the $20^{\text {th }}$ century. He was one of the initial batch of students to participate in the Philippine Studies Summer Program at UP Diliman for international students in 2003. He currently teaches Asian American Literature and Writing at De Anza College in Cupertino, California. 


\section{INTRODUCTION}

The Forum Kritika of a recent issue of Kritika Kultura, "Reflections on Carlos Bulosan and Becoming Filipino," is an important expression of a current within Filipino American Studies that is attempting to connect Filipino Americans to antiimperialist, pro-people movements in the Philippines. E. San Juan Jr. and Jeffrey Cabusao situate Bulosan's post-World War II writing and activism within the broader context of anti-imperialist struggle against the emerging neocolonial regime in the Philippines. Monica Feria, in telling the story of the relationship between Bulosan and her mother Dolores, documents the creation of a united front between middleclass individuals, workers' movements in the US, and workers' and peasants' movements in the Philippines. Marilyn Alquizola and Lane Hiyabayashi highlight the aesthetic struggle of Bulosan in his attempt to both advance and represent the struggle for a free Philippines, a Philippines of the workers and peasants, while Tim Libretti focuses on Bulosan's aesthetic strategies for imagining the relationships of working class Filipinos to one of the major problems that confront them, the larger structures of US colonialism and imperialism. Michael Viola, Valerie Francisco, and Amanda Solomon Amorao do important work in conceptualizing ways in which scholar-activists in the US can support and participate in movements that aim to solve the basic problems that confront Filipinos and Filipino Americans. In their co-written article they explicitly identify the problem of landlessness as one of the key factors in creating the large-scale outmigration of Filipinos from the Philippines. Amorao further elaborates on the necessity for an antipatriarchal and anti-heteronormative stance in considering the history of Filipino working class movements in the US, a stance that Bulosan develops in his literary work.

This monograph is an attempt to build on the work of the Forum Kritika on Carlos Bulosan by considering another aspect of the Filipino diaspora, an aspect that is obscured by a reified conception of the territorial borders of the Philippines and the erasure or misrepresentation of non-Catholics in Filipino history. US imperialism by force set the borders of the archipelago it would govern, despite not only the aspirations for self-determination of the Filipino revolutionaries but also the aspirations for self-determination of Muslims and indigenous peoples who were never truly subjugated by Spain. Christian Filipinos during the US colonial period would in large numbers migrate and settle on the island of Mindanao, a region that during this period was populated primarily by people who did not identify themselves as Filipinos. This diaspora to Mindanao crossed national borders, but national borders that were not recognized by the US colonial state. This diaspora to Mindanao was in fact an instance of settler colonialism. This monograph attempts to clarify the relationships of Filipino Americans to the legacy of settler colonialism in Mindanao with the hope of facilitating solidarity between Filipino Americans and the peoples of Mindanao. ${ }^{1}$ 
To get a better sense of the relationships of settler colonialism in Mindanao to the Filipino diaspora to the US it will be useful to look closely at a passage early in Bulosan's America is in the Heart, perhaps the most widely-read novel in English by a Filipino writer and the central text of Filipino American Studies. ${ }^{2}$ The passage is about the narrator's brother Macario:

When the Spaniards discovered the Philippines in the later part of the fourteenth century, war with the Moros began and continued for centuries. It was both a religious and an economic war, for in those early days of global vandalism the sword and the cross went together. But foreign aggression only made the Mohammedan Moros more ardent defenders of their faith and their land, and even the Christian Filipinos became their enemies when they attempted to impose their customs and laws.

When Macario went to teach in Mindanao, the Moros had not been entirely pacified. But some of their young men and women were already absorbing Christian ideals and modes of living. In fact, the better families were sending their children to America for a liberal education. The sudden contact of the Moros with Christianity and with American ideals was actually the liberation of their potentialities as a people and the discovery of the natural wealth of their land.

My brother Macario sent his monthly earnings from Mindanao to my mother so that we could pay the installment on our land. Then suddenly he stopped writing and sending money. We had one more payment to make. ${ }^{3}$ (47)

Although America is in the Heart is widely read, this passage, to my knowledge, has never received critical attention. The novel, for the most part, tells the story of the narrator, who travels to the US from the Philippines during the Great Depression. Macario, like the narrator, would within a few years travel to the US. Like the overwhelming majority of the young Filipino men who traveled to the US during the 1930s, he would experience tremendous discrimination and violence. Although he was trained as a teacher in the Philippines, which at this time would have normal schools modeled on the normal schools of the US, his employment opportunities in the US would be limited to low-wage agricultural and service work. Macario, like the narrator, would become involved with the labor movement and the organizing for the rights and welfare of Filipinos in the US. At the end of the novel, he would join the US military in order to fight against the occupation of the Philippines by the Japanese military. ${ }^{4}$

The first two paragraphs of this passage make up one of many historical interludes in the novel. On some points, the historical interlude is simply incorrect. Spanish explorers did not arrive on the shores of the archipelago that would later be named Las Islas Filipinas until 1521. Mindanao has never been entirely pacified by Christian invaders. ${ }^{5}$ And most seriously, Bulosan's claim that "the sudden contact of the Moros with Christianity and with American ideals was actually the liberation 
of their potentialities as a people" would be tragically false. It is true that there was a certain "discovery of the natural wealth of their land," but the mineral and agricultural wealth of the island would be plundered to the profit of elite Christian Filipinos and foreign multinational corporations, with Mindanao transformed into a war zone from which hundreds of thousands would be forced to migrate from the 1970 s to the present.

The inaccuracies of the passage are attributable, perhaps, to Bulosan's lack of strong connections to Mindanao. If the connections were as strong as the ones that he maintained with peasants from Luzon, he surely would have discerned the similarities between the plight of his own family and the problems that Christian migration to Mindanao were causing. The narrative in which this historical interlude is embedded is a narrative of dispossession. The narrator's family is dependent on Macario for remittances so that they can make payments on land that they had mortgaged in order to pay for Macario's education. When Macario's remittances end, the family loses its land. Apparently, Bulosan did not consider that the Muslims of Mindanao were, like the family of the narrator, being dispossessed of their lands. The state that was becoming dominated by elite Christian landlords and compradors which would uphold the legal framework for dispossessing the narrator's family was also imposing a legal framework on Mindanao that would facilitate the dispossession of the peoples of Mindanao of their ancestral lands. ${ }^{6}$ Bulosan, unlike those who were petitioning for separate states for the Moro and Christian peoples in the Philippines in the 1930s, was apparently unaware of this process that was unfolding on Mindanao.

It should be remembered, though, that Bulosan was working towards creating international solidarity and building a united front against the fascism of the 1930s and early 1940s. America is in the Heart documents the ties of solidarity between workers in the US and peasants in the Philippines, many of whom would travel to the US after being dispossessed of their lands in the Philippines. ${ }^{7}$ Bulosan's follow-up to America is in the Heart, The Cry and the Dedication, would concentrate on the continuation of the peasant struggles of Central Luzon. The Cry and the Dedication, which is set just after World War II within the peasant struggles against the US-backed, Christian-dominated state of elite Filipino politicians, thus acts as a mediator alongside America is in the Heart since it connects the peasants who remained in Central Luzon with the peasants who had migrated to the US and the workers with whom they had built ties of solidarity. ${ }^{8}$

The Forum Kritika in the recent issue of Kritika Kultura is keeping a certain faith with this project of Bulosan's. I would like to propose that a way to advance this current would be to move beyond the limitations of Bulosan's works, limitations that are visible because of events and movements that have arisen after Bulosan's 
death. It was perhaps because of material, historical constraints that Bulosan could not imagine in any concreteness an alliance between Muslim and Filipino peasants. However, Bulosan articulates, faintly, a desire for such an alliance against the Christian state of compradors and big landlords. The passage about Macario's journey to Mindanao narrates the history of the Philippines in a way that opens up the possibility for alliance because of common long-running struggles against colonialism. It references a time of "global vandalism," when "the sword and the cross went together." The passage thus suggests that the relationship between Christianity and colonialism is not actually essential to Christianity, and that historical circumstances had lead to the co-optation of Christianity by European, and especially Spanish, colonial projects. Furthermore, the passage goes on to suggest that Christian Filipinos are not naturally or inevitably enemies of Muslims. Bulosan traces the religious antagonism to specific actions - the attempts of some Christian Filipinos to impose their laws and customs on the people of Mindanao.

In order to advance Bulosan's project of building international solidarity this monograph addresses two barriers to the solidarity between workers and peasants in the Christian Philippines, Filipinos in the US, and the peoples of Mindanao. The first barrier is the non-recognition on the part of many Christian Filipinos of the diversity of Muslim voices and political positions in the Philippines, despite the existence of many literary and non-literary texts by Muslims in the Philippines. This non-recognition is partially the result of a process of tokenization. Coeli Barry, the editor of The Many Ways of Being Muslim, a recently published anthology of Muslim literature in English from the Philippines, states that Ibrahim Jubaira was in the 1960 s the only Muslim writer whose writings were included in the anthologies of short stories in English that became one of the building blocks for the formation of the field of Philippine Literature in English (9). Since that time, Jubaira almost by default has become the Muslim writer whose work has been selected for anthologization and inclusion on the syllabi of English classes, and his most widely-read work is the story "Blue Blood of the Big Astana." Elsewhere, Barry has read this story as an allegory, in which the "astana," the house within which a Muslim noble lives, stands for the Muslim people. Barry suggests that Jubaira's story articulates the position that the astana must accommodate itself to the Christian state ("Blue Blood"). Perhaps one of the reasons why Jubaira's stories have been so widely anthologized is because this position has been the least troubling one to the editors of anthologies published in Metro Manila and to readers with a Christian bias. I will go on in this monograph to situate this political position within a range of positions that each responded to the question of the relationship of Muslims to Filipinos from the US colonial period up to the present. In the first part of this monograph I will contrast the position advocated by "Blue Blood of the Big Astana," a position that I will call "assimilationist," with a position articulated in many petitions that were sent to the US colonial administration. In 
particular, I will contrast the assimilationist position articulated in "Blue Blood" with a bangsamoro position articulated in the document that has become known as the Dansalan Declaration, a position that defines a moro nation that is distinct from a Filipino nation and that unifies the Muslims who live within the borders of the Philippine archipelago set by the US wars of conquest.

The second barrier to solidarity is the difficulty of many Filipino Americans in recognizing the continuing importance of land to many people in the Philippines. It is a continuing struggle within Filipino American Studies to remind readers and scholars who are studying Bulosan's works about the importance of his links to peasant movements in the Philippines. Because of the differences in the meanings and functions of land in an advanced capitalist society and a semi-feudal/semicolonial society, it is difficult for many readers in the US to discern the dynamism of peoples outside of the cities and the intensity of the struggles around land in the Philippines. The most important of these differences is the differing relationship between land and the livelihoods of the people. The background of much of this monograph is a story of landgrabbing leading to landlessness leading to diaspora and war, leading to the further forced migration of peoples from their lands. The second part of this monograph closely considers a story by Loren Hallilah I. Lao, "The Trip to a Forbidden Land," which was also published in The Many Ways of Being Muslim. The story apparently has no relationship to struggles around land. However, by attending to the specific history of the setting of the story, the Maranao regions of Mindanao, I argue that the story is actually a plea for a peaceful resolution to the conflicts that have caused so much suffering to the Maranao people.

In "The Trip to a Forbidden Land," the setting is in an urban area, and the characters are middle-class. There are thus layers of mediation between the manifest content of the story and the actual conflicts around land that shape it. In the stories that are the subject of the last part of this monograph conflict around land is central. The stories were published in a volume titled Land Tenure Stories in Central Mindanao. The heart of this volume is a set of case studies of land conflict in central Mindanao, and each case study includes the testimony of major actors in the conflicts. The case study that I focus on involves a conflict between an indigenous group, the Ilian Aromanon Manobo tribe, and Muslim families who had settled on the tribe's ancestral lands. These stories show clearly, but in different ways, the relationships between diaspora, landlessness, and wars wrought by US imperialists and the elite Christian landlord and comprador politicians whom they groomed and selected to govern their client state in the Philippines. 


\section{THE FEUDAL AND SEMI-COLONIAL/SEMI-FEUDAL MEANINGS OF LAND IN IBRAHIM JUBAIRA'S “BLUE BLOOD OF THE BIG ASTANA"}

Ibrahim Jubaira was a contemporary of Bulosan's. ${ }^{9}$ Like Bulosan, Jubaira believed that Muslims would prosper by assimilating to the US-Christian state. Also like Bulosan, he apparently had no inkling of what would actually transpire in the southern Philippines later in the $20^{\text {th }}$ century. Ibrahim Jubaira was born in the city of Jolo on the island of Sulu off the coast of Mindanao in 1920. His father, who owned a gold and silversmith shop, was Arab, and his mother was Tausug, the dominant ethno-linguistic group on Sulu (Jubaira, "Father's Control"; Habana 98). In 1933, his parents sent him to Singapore to live with his uncles. Within a year, he moved to Zamboanga, the city that for several centuries had been the Spanish military and trading outpost at the tip of the island of Mindanao closest to Sulu. He completed the teacher training course at Zamboanga Normal School, and he also graduated from Zamboanga A.E. Colleges. While in college, he was editor-in-chief of the college newspaper. For nearly two decades Jubaira taught in public schools in Zamboanga, contributed many articles and columns to local newspapers, and from 1957 to 1959 he edited a magazine. He then began to work for the Philippine government as a technical researcher for the Philippine Congress and as an information officer for the Philippines Commission on National Integration, an agency created by the Philippine government to pacify Muslims in the south (Habana 98-99). He became a member of the Philippine diplomatic corps, with posts in Malaysia, Sri Lanka, and Pakistan (Habana 99; Barry). Ibrahim Jubaira died in 2003.

"Blue Blood of the Big Astana," first published in 1941, is possibly Jubaira's mostread work. ${ }^{10}$ It is the story of a young orphan from the island of Sulu set during the transition between the very nominal rule of Spain over Sulu and the tighter control imposed by the US colonial regime during the opening decades of the 190os, around when Jubaira was born. The story simplifies this transition a great deal, but it highlights its essential features. In this simplified transition, the story draws a sharp contrast between a primarily agrarian economy and one in which commerce becomes dominant. ${ }^{11}$ With some reservations, I will refer to the agrarian economy as feudal, and the commercial one as semi-feudal/semi-colonial. ${ }^{12}$ The plot of the story rests on the unevenness in the development of ideology and the development of the political and economic context. In other words, the plot of the story rests on the continuation of feudal ideologies within a semi-colonial and semi-feudal political economy in which the status of individuals would be based on capital rather than feudal genealogy. 
"Blue Blood of the Big Astana" begins with a brief background of Jaafar, a young orphan in Sulu. Jaafar is raised by his aunt, who weaves mats for a living, but she cannot support him, and so she appeals to a noble with the title of Datu to take him into his household as a servant. The Datu agrees, and the boy becomes the servant of the Datu's daughter. Jaafar becomes infatuated with the Datu's daughter, whom he refers to as "Dayang-Dayang," the title of a young noblewoman. The two grow up together, but then Dayang-Dayang marries the son of another Datu in Sulu. Jaafar runs away from the house of the Datu, and the story continues several years later. The Datu and his son-in-law revolt against the attempts by the US colonial administration to establish control over Sulu. The Datu is killed, and the son-in-law is imprisoned in a "penal farm" in Zamboanga. Jaafar, on the other hand, mysteriously becomes rich. One day Jaafar, in a chance meeting, encounters Dayang-Dayang. She is working with her sons on a small plot of land, since the rest of her husband's land had been confiscated. They have a brief conversation, but after Jaafar leaves and travels for about a mile, he is transfixed by the idea that he could ask Dayang-Dayang and her children to come to his home. Jaafar concludes, though, that such a request would be impossible.

On the face of it, this seems like a rather conventional romance, in which the romantic hero is separated from his beloved by an impassable barrier. The closing lines of the story define this barrier: "That urge to go back to you, Dayang-Dayang, was strong. But I did not go back for a sudden qualm seized: I had no blue blood. I had only a harelip. Not even the fingers of Allah perhaps could weave us, even now, into equality" (14). Jaafar has no blue blood-he does not belong to the Datu class. Furthermore, Jaafar has a harelip, a feature that he attributes to an accident his mother had while she was pregnant with him. This feature plays an important role in the childhood relationship between Jaafar and Dayang-Dayang-she makes fun of his harelip, and he laughs along with her; he fantasizes about tickling her face with his harelip; Jaafar even endures punishment on behalf of Dayang-Dayang at her school by having his harelip clipped together by the teacher $(6,8,9)$. In conjunction with his short stature when he and Dayang-Dayang were children, the harelip makes it seem impossible that they could ever be equals; thus, he is permitted an intimacy with Dayang-Dayang that a taller or more handsome young man could not have (8).

What is not mentioned in the closing lines of the story, though, is a difference in concepts of wealth. The story itself illustrates this in its descriptions. Jaafar describes the young datu who marries Dayang-Dayang in feudal terms: "The young datu was handsome. And rich, too. He had a large tract of land planted with fruit trees, coconut trees, and abaca plants" (9). Land and the agricultural production of the land is the primary form of wealth, and the punishment for revolt against the US colonial administration is described as the expropriation of land. Jaafar 
addresses Dayang-Dayang in an apostrophe: "Your husband, to save his life, had to surrender. His lands, too, were confiscated. Only a little portion was left for you to cultivate and live on" (11). In the semi-feudal/semi-colonial situation created by the US conquest of Sulu, Dayang-Dayang takes on the status of a small peasant landowner, cultivating her own land. Jaafar, upon seeing Dayang-Dayang and one of her sons, thinks to himself of the labor that they must do in order to survive: "Poor little Datu, working so hard. Poor pretty Blue Blood, also working hard" (12).

In contrast, Jaafar becomes a cattle merchant. In the conversation between Jaafar and Dayang-Dayang after she has entered the peasant class, Dayang-Dayang describes wealth in terms of land, while Jaafar describes his activity as buying and selling:

We kept silent for a long time. And then: By the way, where was I living now? In Kanagi. My business here in Bonbon today? To see Panglima Hussin about the cows he intended to sell, Dayang-Dayang. Cows? Was I a landsman already? Well, if the pretty Blue Blood could live like a countrywoman, why not a man like your old servant? You see, luck was against me in sea-roving activities, so I had to turn to buying and selling cattle. ${ }^{13}(12)$

Jaafar, in contrast to Dayang-Dayang, conceives of wealth primarily in terms of commodities - his wealth consists of cows and the ability to buy and sell them. The old concepts of class - the feudal hierarchy of Datus, panglimas, servants, and "natives" - and the concepts of human relationships based on this class hierarchy are put into crisis by new concepts derived from the relationships of individuals to commodities and their production, exchange, distribution, and consumption. ${ }^{14}$ Genealogy, likewise, becomes unimportant-blood is of no concern when it comes to commodities. ${ }^{15}$ However, the new society is not simply a capitalist society because residues of the feudal order persist. Even though colonialism is formally established, feudal ideologies and cultural remnants survive. "Blue Blood of the Big Astana" illustrates the way ideologies are embodied even when their political and economic bases have shifted. The story is thus not simply a romance; rather, it is a story about a very abrupt transition in Sulu from a feudal mode of production to a semi-colonial, semi-feudal one. ${ }^{16}$

The categories of feudalism, semi-colonial, semi-feudal, and mode of production, of course, were certainly not ones that Jubaira would have chosen to describe his story. The story gives no indication that the natives or the servants, not to mention the farmers who actually worked in the fields, could change their social conditions through collective action. Jaafar, in his narration, notes the work that DayangDayang and her son must do in order to survive after their lands are confiscated by the Christian government, but he never considers the fact that the overwhelming 
majority of people on Sulu had to work just as hard. Instead, the story is told from an emerging middle-class perspective tied to the increasing importance of the commercial, capitalist economy. Furthermore, this middle-class perspective is likely more tied to Jubaira's position in Zamboanga, the center of Christian power in the region, rather than his roots in Sulu. This middle-class perspective, though, would itself be mixed insofar as within this class perspective there were differing political positions towards the Christian government. The attitude expressed in "Blue Blood," what I will call an assimilationist position, is articulated most fully in the following paragraph:

And Allah's Wheel of Time kept on turning, kept on turning. And lo, one day your husband was transported to San Ramon Penal Farm, Zamboanga. He had raised his hand against the Christian government. He has wished to establish his own government. He wanted to show his petty power by refusing to pay land taxes, on the grounds that the lands he had were by legitimate inheritance his own absolutely. He did not understand that the little amount he should have given in the form of taxes would be utilized to protect him and his people from swindlers. He did not discern that he was in fact a part of the Christian government himself. Consequently, his subjects lost their lives fighting for a wrong cause. Your Appah, too, was drawn into the mess and perished with the others. His possessions were confiscated. And your Amboh died of a broken heart. Your husband, to save his life, had to surrender. His lands, too, were confiscated. Only a little portion was left for you to cultivate and live on. (11)

This passage refers to the revolts that occurred on Sulu that flared up sporadically from shortly after the arrival of US forces up to the $1920{ }^{17}{ }^{17}$ Initially, when the Philippine-American War began, the US government employed a policy of attraction towards the Sultanate of Sulu by pledging to not interfere with the society of the islands controlled by the Sultanate. However, after the US military had devastated Filipino communities that opposed US rule in Luzon and the Visayas, US military governors in the Southern Philippines imposed several measures that resulted in a series of revolts, measures such as the disarmament of Muslim warriors, the abolition of slavery, and, as the passage from "Blue Blood" references, the imposition of taxes (Macasalong 56; Remollino 177).$^{18}$ The passage goes on to articulate the basic premise of the assimilationist position: that the Christian government, which in 1941 was transitioning from direct US rule to indirect rule by elite Christian Filipino compradors and big landlords, would be benevolent. Furthermore, the passage states that the Christian government would protect the property of Muslims from "swindlers," those who would dispossess the people of Sulu. The most important form of property, for the overwhelming majority of people on Sulu, would be land, the source of livelihood. As we will see later in this monograph, the Christian government would itself become the major agent in dispossessing Muslims of land. 
Jubaira's assimilationist position was not popular. Jubaira, most likely, was responding to a much more popular position, one adamantly opposed to Christian Filipino rule of Mindanao and Sulu. In the mid-1930s, in the years just prior to the publication of "Blue Blood of the Big Astana," a combination of anti-Filipino sentiment in the US that wished to prevent the movement of Filipino workers to the US by classifying Filipinos as "aliens," and the agitation of Filipino landlord and comprador politicians, resulted in the Tydings-McDuffie Act of 1934, which set a ten-year timetable for independence for the Philippines. Shortly after the passage of the Tydings-McDuffie Act, in 1935, a letter, signed by over 100 Maranao leaders, was sent to President Franklin Roosevelt and the US Congress. This letter, which would become known as the Dansalan Declaration, articulated a Moro identity, an identity for the Muslim peoples of Mindanao and Sulu. ${ }^{19}$ The letter predicted disaster for the Moros if they were placed under Christian Filipino rule:

We would like to inform you (i.e. U.S. Congress) that because we have learned that the U.S. is going to give the Philippines an independence...we want to tell you that the Philippines...is populated by two peoples with two different religious practices and traditions. The Christian Filipinos occupy the islands of Luzon and the Visayas. The Moros predominate in the islands of Mindanao and Sulu. With regard to the forthcoming Philippine Independence, we foresee what the condition we will be in and our children when independence is granted these islands. This condition will be characterized by unrest, suffering and misery... (Therefore) we do not want to be included in the Philippines Independence (for) once an independent Philippine is launched there will be trouble between us and the Christian Filipinos because from time immemorial these two peoples have not lived harmoniously...It is not...proper to have two antagonizing peoples live together under the Philippine Independence. One proof of this (is) when Lanao had its (Christian) Filipino Governor, many leading Moro Datus were killed for no apparent reasons. ${ }^{20}$

This quotation predicts that Christian Filipino rule over the Moros would lead to unrest, suffering and misery for the Moro people. Furthermore, the signatories state that a Christian government would be antagonistic to the Moros, and this antagonism had already taken the form of political repression such as the killing of Moro leaders. ${ }^{21}$

Elsewhere in the letter, the signatories describe the inequalities that had already developed, inequalities that were also causing alarm among the Moros. ${ }^{22}$ First of all, the signatories state that the Christians had excluded Moros from positions of political power, positions of administration and management, in the colonial government. Secondly, the Christian-dominated government took control of the insular funds that were distributed from the administrative center of the colonial government in the Philippines. Moros were thus prevented from participating in 
the development of urban societies, enjoying the benefits of "modern civilization," and participating in "modern education."

The solution that the letter requests from the US government is for it to retain control over Mindanao and Sulu. The signatories, on the surface, were apparently misguided in believing that the US government would really act in the best interests of the Moros. Clearly, they chose not to mention the causes of revolts and the brutal repression of those revolts that had occurred under US rule. Given the situation that they were facing and the specific aim of the letter, it is somewhat understandable that the signatories would praise the US colonial administration. However, the part of the letter that would prove well-founded is the description of the threat that the rule of elite Christian Filipinos would become. The accuracy of the description of the US colonial administration is questionable, but what the description makes clear is the kind of political and economic situation that the signatories desired. The description gives praise to an administration that respects the religion, customs, traditions, and practices of the Moros. The description gives praise to an administration that recognizes the rights of the Moros to their property, which, as we will see, refers primarily to land as the provider of livelihoods. Finally, the description gives praise to an administration that directs its efforts for the welfare of its people. By implication, the Moros had no confidence that the rule of Christian Filipinos would enact this kind of political and economic situation.

When the Dansalan Declaration was sent to Franklin Roosevelt, Jubaira had just arrived in Zamboanga, a city to the west of Lanao, the province in which the declaration was signed. ${ }^{23}$ Historically, Zamboanga has been the point of connection between the three major Muslim polities, the archipelago of the Sulu Sultanate, the Maguindanao Sultanate inland from the western coast of central Mindanao, and the Pat a Pangampong a Ranao around Lake Lanao in the north central region of Mindanao. The Spanish established the fort of Zamboanga in 1635 in order to divide the Muslims of Mindanao and Sulu, and shortly after US soldiers took control of the fort, it became the seat of the colonial government in the newly-created Moro Province in 1903. It is in Zamboanga where Jubaira would receive much of his education, and it is from Zamboanga that Jubaira wrote "Blue Blood of the Big Astana." It is possible that Jubaira was not aware of the Dansalan Declaration until long after he wrote "Blue Blood," but his location in Zamboanga, a long-established Christian stronghold on Mindanao that was the administrative center of the US colonial government in the Southern Philippines, as well as Zamboanga's position at the intersection of routes between the Muslim peoples of Cotabato, Lanao, and Sulu, meant that he would have been well aware of the popular opposition to Christian Filipino rule. During the 1920 s and 1930s, several petitions from the people of Sulu, Lanao, and Cotabato urged the US government to take steps towards preventing economic and political domination 
of the Southern Philippines by Christians from the north. During this time an emerging bangsamoro consciousness, a national consciousness among Muslims in the Philippines, developed between people in Sulu, Lanao, and Cotabato who recognized the common problems faced by Muslims within the territory of the Philippines. Evidence for the emergence of this consciousness comes from the petitions to the US government circulated by Muslims, several of which arose in Zamboanga. ${ }^{24}$

\section{SETTLER COLONIALISM AND THE ABSENCE OF PEACE IN "THE TRIP TO A FORBIDDEN LAND"}

The history of Sulu during the US colonial period, the setting of "Blue Blood of the Big Astana," contrasts significantly with the history of Lanao, the home province of those who signed the Dansalan Declaration. ${ }^{25}$ The major contrast is the differing impact of settler colonialism. Lanao, in contrast to Sulu, became the destination of a huge influx of Christian settlers that would have devastating impacts on the Muslims of Lanao. During the US colonial period from 1903-1939, the bulk of the migrants to Mindanao settled in regions adjacent to the regions dominated by Spain, on the coast of North Central Mindanao, north and northwest of Lake Lanao. In Lanao, three quarters of the population growth during this period was the result of in-migration. Between 1903 and 1939, about 165,000 people migrated to Lanao, and between 1948 and 1960, an additional 165,00o people migrated (Wernstedt and Simpkins 89, 92). ${ }^{26}$ The arrival of so many Christian settlers split the province into two parts, and in 1959, Lanao was partitioned into two provinces, the predominantly-Christian Lanao Del Norte and the predominantly-Muslim Lanao Del Sur.

Loren Lao, a writer based in Lanao Del Sur, like Jubaira writes from a middleclass perspective. Lao is an attorney who has taught in the English department, the College of Law, and the Communication and Media Studies department at Mindanao State University in Marawi City ("Loren Hallilah I. Lao"). She has published several articles that document the efforts of Muslim women to educate and organize each other in defense of their rights with a special emphasis on women who consider the rights of women in a way that is consistent with Islam. ${ }^{27}$ She has also written a chapter in a report for the United Nations Entity for Gender Equality and the Empowerment of Women on projects for popular education and consultation among Bangsamoro women concerning the Convention on the Elimination of All Forms of Discrimination Against Women (CEDAW) ${ }^{28}$

To my knowledge, Lao has published only two works of fiction, both in the anthology The Many Ways of Being Muslim. One story, "Good Old Bapa," depicts 
the plight of a 15 year-old girl who is married, clearly without her consent, to a much older man. ${ }^{29}$ The other story, "The Trip to a Forbidden Land," highlights tradition. The immediately obvious conflict at the center of "The Trip to a Forbidden Land" involves the observance of a marriage tradition which is presented as a tradition that is very particular to the area around Lake Lanao. At first glance, the conflict seems to be generational. The central character, Asnia, attends the funeral of the aunt-by-marriage who raised her husband. Asnia's mother, who is "rather strict with traditions," is furious because her son-in-law's family had not sought out the bride and held a kalawi, during which the groom's family would escort the bride from her home to the hometown of the groom, to welcome her daughter into the family (152). Only after a kalawi would the bride be able to travel freely to the hometown of her husband.

The basic argument that I would like to make about "The Trip to a Forbidden Land" is that it is ultimately a plea for peace, a plea that must be understood in terms of the barriers to peace and the experiences of war and diaspora that are particular to the Lanao region. The story, much of which is told almost in the form of a drama, revolves around a single scene of domestic conflict. In the first part of the scene, Asnia's mother visits her very early in the morning, and the two argue about Asnia's visit to the hometown of her husband. The argument is interrupted when two of Asnia's sisters-in-law arrive at the apartment. Asnia's mother rushes her into the restroom, answers the door, and tells the two guests that Asnia is not at home. Asnia's mother and the two sisters-in-law engage in a brief and awkward standoff. The sister-in-law who needs to use the restroom insists on using it, and after the other sister-in-law leaves the door Asnia's mother lets her inside. The story ends with Asnia's mother touching her in-law's arm and asking, "Please try to understand me" (159).

What bestows the plea for peace its poignancy is the conflict that permeates the Lanao region. Lao's story is one of domestic conflict, conflict within a single household, in which the antagonists are women. However, with the arrival of Asnia's sister-in-law, the domestic conflict spills over into a space occupied by multiple families. Inter-familial conflict, often called rido, is a major concern in Lanao del Sur. Rido names a kind of clan conflict or feud characterized by a series of acts of violence and retaliation. ${ }^{30}$ In Lanao del Sur, the number of rido declined after the early 1990 s and then spiked in the early 2000 (78). In Mindanao and Sulu as a whole, the number of rido increased steadily since the 1980s, and the number of documented cases of rido doubled from the year 2000 to 2004 (Torres 16). In contrast to the domestic scene of conflict in the story, in which all of the major participants are women, in the rido of Lanao del Sur, it is extremely rare for women to be the assailants in carrying out retaliatory violence, and the overwhelming majority of victims of retaliatory violence have been men (Matuan 83). ${ }^{31}$ The 
emergence of a rido has devastating effects on families. In many cases, families migrate away from the area, limit their movements within the affected areas, prepare defenses against possible attacks, provide support to family members in trouble, and experience serious effects on their economic activities (Matuan 85). For many families, valuable time and energy is devoted to attempts to settle the rido, and within the communities as a whole many feel alarmed.

The backdrop of inter-clan conflict increases the tension and the stakes of the closing paragraphs of Lao's story. Repeatedly in the story, the characters avoid conflict. ${ }^{22}$ Asnia's husband Omar, very early in the morning, lets his mother-inlaw and Asnia's younger brother into the apartment, and he quickly recognizes from the tone of her voice and her "tensed up bearing" that something is wrong (152). He wakes Asnia, waits for her to get up so that he does not have to face his mother-in-law, and then quickly leaves his wife to confront her mother alone. Asnia initially tries to distract her mother by beginning to discuss buying clothes for her siblings, but her mother forces a confrontation about Asnia's visit to her husband's hometown. Asnia's little brother, once he realizes that his mother and elder sister are beginning to argue, leaves the room and plays in the dining room. The argument continues with Asnia's mother heaping abuse on Asnia's sisters-inlaw, who had also visited their husbands' hometown without receiving a kalawi. The two sisters-in-law, Sairah and Noraisah, knock on the door to the surprise of Asnia's mother. Asnia's mother tells Asnia to wait in the restroom, and after opening the door she tells Noraisah and Sairah that Asnia is not home. After a brief standoff at the door the story concludes:

"Why don't we just go? We have to hurry." It was Noraisah urging Sairah to leave, sensing something wrong with the unmoving stance of the older woman at the door. She felt that they were not welcome and so tried to dissuade her companion from going inside.

"But I [Sairah] really have to go."

"Eee, why do you have to go?"

"I really have to."

“Ok, I'll just wait in the car." At Noraisah's remark Asnia's mother relaxed at the doorframe. Noraisah then turned to leave and went back to the car.

"Ok," Sairah said as the woman at the door let her in. Sairah quickly went in the direction of the sole comfort room in the apartment. As she reached for the knob of the door, the older woman touched the arm that held the knob stalling Sairah from going inside.

"Please try to understand me." (159)

Even Noraisah, whom Asnia had described as domineering, avoids a confrontation with Asnia's mother. Sairah, whose personality had been characterized as milder 
than Noraisah's, insists upon using the restroom despite the posture of Asnia's mother. When Noraisah leaves the door, Asnia's mother visibly relaxes and allows Sairah into the apartment. Perhaps Asnia's mother believes that Sairah will not cause further trouble, which might ensue if Noraisah remains. At any rate, the gentlest gesture from Asnia's mother in the whole story is directed towards Sairahshe simply touches Sairah's arm to get her attention.

The final line of the story-"Please try to understand me"-suggests that the conflict between Sairah and Asnia's mother, and more generally the potential conflict between the clan of Asnia's mother and the clan of Asnia's husband, can be resolved through understanding. The statement is thus a plea for peace in terms of a method for maintaining peace. In other words, in order to avoid conflict, Asnia's mother asks Sairah to understand the situation and presumably to act accordingly. Asnia's mother seems to recognize her error as she anticipates Sairah learning that she has lied about Asnia not being at home. Furthermore, Asnia's mother had not been hospitable when she initially refused to let Sairah use the comfort room. Sairah would have a legitimate grievance, and she would then have the choice either to condemn Asnia's mother without further knowledge, or to find the more basic problems that had created the situation where Asnia's mother lied to her so that she could understand the situation better.

The form of the story itself suggests that understanding is very difficult. In order to articulate the causes of the conflict, the story must actually break from its narrative flow. Within "The Trip to a Forbidden Land," there is a tension as an anthropological discourse, a commentary detached from the flow of the plot contained within two paragraphs in the middle of the story, interrupts the dramatic narrative:

A bride is not supposed to go to the groom's hometown, especially when he comes from a different place, not until his relatives have gathered to look for the girl and take her to their place for the kalawi. There, a kalilang and a feast would be held in honor of the bride to welcome her to the place of the groom. Speeches extolling the visiting relatives-in-law would be delivered. For really grand kalawi, gifts such as parcels of land would be given to the bride and money would be distributed to her relatives. And to top it all, a tankong awaits the bride while her new relatives wash her feet, the pamorawas, after which she is finally carried by her relatives-in-law to the house where the feast is to be held.

Many do away with this custom because of the expense it entails but many, especially those from the Basak area where Asnia's mother came from, are still quite strict about 
this. There are absurd stories of married couples whose children had already grown up and yet the wife had not yet stepped in her husband's place. An aging mother-inlaw laments that when she, this mother-in-law, eventually dies, her sole daughter-in-law cannot go to the tibao because her son's wife was not able to attend her husband's burial because his relatives had not yet complied with the lawi. While busy with the gawi-i, the poor man's relatives had to make arrangements for the lawi of his wife so that she could go to her dead husband's hometown and see his grave. Another couple got married and years later divorced but the wife had not seen her estranged husband's place during the entire period of their marriage because the husband's relatives had not looked for her. $(156-7)$

Lao apparently felt it necessary to provide some background for readers who would have no idea about the ways in which conflicts would be articulated within a middle-class Maranao domestic space. In other words, Lao herself seems to recognize that the lack of historical and cultural knowledge on the part of her English-speaking readers would be barriers for interpreting the story, and she addresses this lack through a shift in the way in which she writes the story.

The anthropological discourse, though, is not really detached insofar as it is bound by the perspective of a specific socioeconomic class, an urbanized middleclass. What is missing in this story is a way to place this middle-class within the totality of socioeconomic classes in Lanao. It will be necessary, then, to consider the ways in which this domestic space is contextualized within a society that is structured by differences along the lines of socioeconomic class because the activity of understanding, without any change to the economic basis and the structure of political power of the society, does not solve the basic problems that create conflicts. The economic base of Lanao is predominantly agricultural, and the dominance of the Christian state has resulted in Muslims having less and less access to land. The interlude into anthropological discourse in the story, which also involves a periodization, gives only a few hints about the economic and political shifts that have resulted in so many people of Lanao suffering from war and forced migration. The two paragraphs of the interlude explain the practices around lawi and relate anecdotes about the lengths to which the practices were observed. In the next paragraph, the story returns to the narrative by describing the attitudes of the family of Asnia's husband Omar while simultaneously telling a sort of origin story for the middle class:

Omar told his wife that his relatives no longer observed such things. The practice was possible before when, very few married outside their place. Now that more and more men in their family marry the girls they meet in school, the office or somewhere else, girls who came from places all over the Ranao ${ }^{33}$ but not from their hometown, the 
traditions could no longer be kept. From their brood alone, four of the six boys married girls who came from different places. All his Babo [Aunt] Amina's three sons married girls from outside their hometown. And there are still countless cousins who married outside their town. If they look for all these girls for the kalawi, where would they get all the money to spend for the feast and kalilang? $(157)^{34}$

The paragraph divides the history of Omar's family into two periods, and it makes explicit certain historical shifts that created the conditions for the conflict between Asnia and her mother. In the first period, kalawi could be held without being a burden. Presumably, this was an agrarian period, in which travel and migration was not common, in which the town and its surroundings were self-sustaining. In the second period, the period when a middle-class created by the inroads of semicolonial capitalism began to develop, it would be impossible for the family to afford to hold kalawi for all the young men who married young women from outside their hometowns. The second period is one in which an urban middle-class develops, a middle-class in which some young people would migrate for education away from their hometowns, would search for middle-class employment (presumably in offices) away from their hometowns, and would venture from their hometowns because their livelihoods would no longer be so directly connected to agricultural production.

Markers of being middle-class are scattered throughout the story. Omar works in an office and drives a car; Asnia apparently does not need to work, and the couple lives in an apartment; Asnia's sisters-in-law arrive at the apartment in a car. Furthermore, the family is relatively urbanized: Omar's parents worked in the city, Omar went to high school in the city, and Asnia's sisters-in-law arrive at her apartment on the way to the city of Cagayan de Oro. However, it would be an analytical error to overlook the specificities of middle-class existence in this region of Mindanao. The middle-class would be only a small fraction of the population. The overwhelming majority would be tied to the land and to agriculture. ${ }^{35}$ Many who had migrated to the cities to seek work would have an agricultural background and would have direct experience with working on the land. Even those who seem relatively well-off, such as the aunt of Omar, would likely be involved in some kind of agricultural production for their own consumption.

The class position of Asnia and her family, and the position of the domestic scene within an urban area, imply that the relationship of the events in the story to the land is highly mediated. Nonetheless, land does appear, albeit briefly, in the description of practices around a kalawi, most notably in the references to gifts of parcels of land (156). It is necessary to pause here for a moment and dwell on the contrast between the meaning of land in a fully-developed capitalist society in contrast to the semi-feudal, semi-colonial setting of the story. In a capitalist society, 
land is not the primary means of production, and wealth is measured primarily in terms of money. Land is merely one of many commodities reducible to money, and it is rarely given as a gift. In fact, once the payment is complete and the title changes hands, it would be unusual for the buyer and the seller to stay in contact since their relationship is first of all determined by the circulation of money-once the transaction is complete, there is no reason for the buyer and seller to continue their relationship. In the prior moment evoked in the story, however, land is a means of production and itself a means for livelihood. Furthermore, the holding of land is embedded in the life of the community. Land is not alienated through the negotiation of contracts and the exchange of titles, which is likely to occur behind the closed doors of banks and real estate agencies. Instead, the transfer of land tenure is done during an elaborate ceremony with many witnesses. The transfer of land in the kalawi signifies the full acceptance of the bride into an honored place in the life of the groom's family. The community itself guarantees the right of the bride to the land.

In the setting of "The Forbidden Land," the community which previously guaranteed rights to land must contend with outside forces that shift the meaning of land. The context is one in which land is alternately regarded as, on the one hand, a means of production, a place of domicile, and for a family a marker of wealth and status within the community; on the other hand, land is regarded as one of many commodities that can be possessed simply through a cash transaction guaranteed by the state. This doubling of meanings is characteristic of the semifeudal/semi-colonial situation of this region of Mindanao. The double-ness arises from the expansion of commodity-based economies into the region, with the result that money gains increasing importance in the lives of people living there. This double-ness is visible in the descriptions of the kalawi within the story. The bride in particularly grand kalawi would sometimes receive land, and the relatives would receive money. The situation that demands a kalawi, in which a son marries a woman from outside of the son's hometown, becomes more common, and thus Omar's family feels that it cannot afford to continue the tradition. The story goes on to articulate how the previous importance of the land has faded while the importance of the money/commodity economy ascended: "Many do away with this custom because of the expense it entails" (156). The term "expense" is ambiguous insofar as it is not clear whether the expense is in money or in land.

The paragraphs that give a brief anthropological account of the conditions that lead to the decline of the observance of the kalawi provide a sense of how historical shifts within Maranao society lead to a domestic conflict, the conflict between Asnia and her mother, and the potential for an inter-clan conflict. However, just as it is important to consider the domestic space of the conflict within the wider space of Maranao society, it is important as well to consider the links between this 
domestic conflict and other conflicts within Maranao society and the role of the Philippine state and the US colonial administration in Mindanao in creating these conflicts. The economic and political conditions that lead to the formation of the urban middle-class in Lanao Del Sur are the ones that have lead to the proliferation of other conflicts, such as rido. A double-ness appears in the description of the kalawi in "The Trip to a Forbidden Land," with the older meaning of land coexisting with the newer capitalist conception of land. The tradition of holding kalawi, however, is not integral to the newer capitalist society within which the domestic space constructed by the story is situated, and the characters in the story are put into a position where they must choose between upholding the tradition or not. The choice is not neutral, because in order to uphold the tradition characters within the story would have to endure hardships within the capitalist society. The double-ness that is visible in "The Trip to a Forbidden Land" is tied to the violence that previous Maranao society has endured through the course of the $20^{\text {th }}$ century, a violence that has created a double economy and a double political structure and has also created conditions that have lead to conflicts within Muslim communities.

Within Maranao society the most prevalent causes of the development of rido in recent years have involved electoral violence and land disputes. These two causes are intertwined. Electoral violence escalated after 1991, when locally elected government officials gained control of Internal Revenue Allotment funds-what some might call a "pork barrel"-distributed by the national government of the Philippines. Meanwhile, the political authority of traditional Maranao community leaders, who in previous times settled conflicts over land, has been eroded. Moctar Matuan aptly describes one way in which the doubling of the political structure within Lanao del Sur, between the older Islamic and traditional authority and the authority of the national government of the Philippines, has created the conditions for the proliferation of rido:

The Meranaos have their own concept of land ownership heavily influenced by Islam. For this reason, many land owners do not bother to title their land under Philippine laws. As the old folk pass away and the new generation inherit the land, disputes over ownership and boundaries increase. There are cases where an educated family or clan member placed communal land under his own name precipitating intra-clan feud. The conflict between the Meranao concept of land ownership and that of the Philippine government "legal system" was the second major cause [behind electoral violence] of conflict and rido in Lanao del Sur. (79-80)

As Matuan describes it here, rido has arisen in some cases because unscrupulous Muslims have been involved in land grabbing, relying on the legal authority of 
the Philippine government instead of the traditional structures of land tenure to guarantee their titles to land at the expense of their own relatives. However, this kind of land grabbing is tiny in scale in comparison to other forms of land grabbing whose origins are in the US colonial regime in Mindanao. From very early in the US colonial regime, and continuing through the periods of the Commonwealth and the Government of the Republic of the Philippines, the colonial and then the neocolonial administrations attempted to relieve the pressures caused by landlessness, produced by prior cases of land grabbing perpetrated by Filipino elites against the peasants of Luzon and the Visayas, by encouraging people to migrate from Luzon and the Visayas to Mindanao. ${ }^{36}$ Furthermore, shortly after the US made the Philippines into a commonwealth the Philippine Commonwealth Government took legal steps that facilitated land grabbing by Christian settlers. In 1936, Commonwealth Act 141 declared all ancestral lands of Muslims and indigenous peoples "public lands," which meant that the lands became subject to the private ownership of individuals and corporations. Maranaos, unaccustomed to the land titling process imposed by the US and then the Philippine governments, became vulnerable to losing their lands when settlers applied for legal titles. Especially after World War II, the number of cases of land disputes multiplied. In one month in 1962, a list of cases compiled by the Commission on National Integration involved 20,000 hectares of land. ${ }^{37}$ These cases would most often be decided against Muslims. ${ }^{38}$

Just as land disputes between Muslims are tiny in scale in comparison to the historical land disputes between Muslims and Christian settlers, so the violence between Muslims has been tiny in scale in comparison to the violence that Christian settlers and the Christian state have inflicted on Muslims since the 1970s. Settler colonialism, encouraged by policies of the US-colonial regime and then the government of the Republic of the Philippines, lead to violence and the displacement of Maranao people on a catastrophic scale. From late-1970 to mid-1972, a Christian militia group named the Ilaga attacked Muslim communities in many provinces of Mindanao, including Lanao del Norte and Lanao del Sur. From April 6 to July 22, 1971, 52 houses of Muslims were burned in the municipality of Wao in Lanao del Sur (Lingga 14). In November of 1971, Philippine Army soldiers stationed in Barrio Tacub, Kauswagan, Lanao del Norte, massacred over 30 unarmed Muslims who were returning home after attempting to vote (Bentley 253). In the most infamous incident of this period, the Manili massacre in the municipality of Carmen in North Cotabato, the Philippine Constabulary called a meeting at a mosque on June 19, 1971. Once the meeting had gathered, the doors were bolted and a grenade was thrown into the building, killing 70 people, including women and children (Macasalong 100-101). 
The loss of land and the violence of war that have been inflicted on the Maranao people have created a massive diaspora of internally displaced persons. In 2002, within the Philippines, 706,585 people of Maranao descent were living outside of the regions traditionally inhabited by the Maranao people, over a quarter of the total population of Maranao (Busran-Lao 33). After leaving their homes, many Maranaos experience discrimination and exploitation. Basic services such as health care are difficult to access due to discrimination based on their religious difference from Christian health care providers, and they are denied economic opportunities such as access to credit and employment in offices and firms because they are Muslims. When deaths occur, there is often tremendous hardship in finding a suitable burial place. Women who are displaced are vulnerable to human trafficking, and there is sometimes pressure on them to consent to polygamous marriages (Busran-Lao 36). ${ }^{39}$

The history of Cotabato, the region to the south of Lanao, has paralleled the history of Lanao. Both provinces were formed in 1914 by the US colonial administration, and in both provinces both the US colonial administration and the Government of the Philippines created programs that brought settlers from the Northern and Central parts of the archipelago. Muslims in both regions thus experienced massive demographic shifts. In 1918, in the province of Cotabato, the population of non-Muslims was 61,052, while the population of Muslims was 110,926 . Muslims constituted $64.53 \%$ of the population. Between 1939 and 1948 , the population of non-Muslims more than doubled, while the number of Muslims actually declined. ${ }^{40}$ By 1960, the number of non-Muslims grew to 672,659, while the population of Muslims grew at a much slower rate to 356,460 . In 1960, Muslims made up only $34.64 \%$ of the population of Cotabato. As a result of these demographic shifts, Cotabato was partitioned into Christian and Muslim provinces in 1966, just as Lanao had been partitioned in 1959. North Cotabato was further partitioned in 1973, and currently only one of the three provinces carved out of North Cotabato, the province of Maguindanao, is majority Muslim..$^{41}$

Both Lanao and Cotabato experienced war during the 1970s, and both experienced refugee crises as people were driven from their homes by militarized conflict. The Ilaga Christian militia groups first appeared in North and South Cotabato before extending their reach to Lanao Del Sur, Lanao Del Norte, and other parts of Mindanao (Busran-Lao 10-11). In response to the escalation in violence in Mindanao perpetrated not only by Christian militia groups but also the armed forces and police of the Philippine state, and in response to the declaration of Martial Law by Ferdinand Marcos, Muslims in Mindanao and the Sulu archipelago launched the Moro National Liberation Front (MNLF) in order to struggle for selfdetermination. The MNLF enjoyed wide popularity among Muslims in all parts of what would become the Autonomous Region of Muslim Mindanao (ARMM). 
However, the war for the Bangsamoro nation would sow immense destruction, with an estimated death toll of 100,000-120,00o for the years between 1972 and 1976 (Montiel et al. 79). Nearly 75\% of the troops of the Armed Forces of the Philippines were deployed to Mindanao and Sulu during this time (Hedman 3). Tragic as these numbers are, they show not only the brutality of the Philippine military but also the depth of support for the MNLF. Approximately 50\% of those killed were MNLF combatants, with 30\% from the Philippine military, and 20\% civilians (Montiel et al. 79). During this period, the scale of the displacement of people in Mindanao and Sulu was horrendous, and the aftermath of the massive escalation of the war continues to affect the lives of people in Mindanao. More than a million people were made homeless and destitute, and 200,000-300,000 Muslims were forced to flee to other parts of the country and even to Sabah in nearby Malaysia (Buendia 4).

In Lao's story, the forced migration of Muslims and the problem of landlessness are far in the background and nearly undetectable. The focus of this monograph will shift to stories about land conflict in which the connection between land and livelihood is very clear. The stories of land conflict are separated from Lao's story by a division in economic class. In contrast to the urbanized, middle-class characters of Lao's story, the characters in the stories about land conflict are farmers on small plots of land. Furthermore, while Lao's story is fiction, the stories of land conflict are non-fiction. The stories are recorded in a volume entitled Land Tenure Stories in Central Mindanao, published by the Kadtuntaya Foundation in partnership with the Mediators Network for Sustainable Peace and the Local Governance Support Program in ARMM. The centerpiece of this volume is a series of case studies of conflicts over land in which the writers attempted to allow parties on each side of the dispute to tell their own stories with the aim of finding regions of agreement that would lead to peaceful resolutions of the conflicts. ${ }^{42}$

\section{INTERNALLY DISPLACED AND INDIGENOUS PEOPLES}

The case study I will focus on here involves a dispute between Muslim families and a group of indigenous people. The Muslim families had been aided by the Moro National Liberation Front, and afterwards by the Moro Islamic Liberation Front (MILF). ${ }^{43}$ Even though both Moros and indigenous peoples in Mindanao have been victims of policies of the US colonial regime and the Philippine state, relationships between Moros and indigenous peoples have often not been harmonious. In some ways, the story in this section mirrors the story told in the previous section of this monograph, in which Christian settlers, who were likely dispossessed of lands themselves, displaced long-established Muslim communities through the sponsorship of the US and Philippine states. In this section, Muslims who were displaced in turn displace indigenous peoples. 
The group of indigenous people belongs to the Ilian Aromanon Manobo Tribe. A major political factor in building the collective strength of indigenous peoples in Mindanao is the founding of Lumad Mindanaw in 1986, which was an important moment in the creation of a movement for the self-determination of indigenous peoples on Mindanao. Fifteen tribes of Mindanao, including representatives from the very large Manobo tribe, participated in the founding congress in Cotabato. The congress chose to name the indigenous tribes collectively as Lumad, the Bisayan term for native (Rodil). Furthermore, indigenous peoples won recognition from the Philippine state through the Indigenous Peoples' Rights Act (IPRA) of 1997, which would provide a legal mechanism for titling the ancestral domains of indigenous peoples to indigenous communities and which would lead to the creation of the National Commission on Indigenous Peoples (NCIP). ${ }^{44}$ In recent years, indigenous groups in Mindanao have raised concerns that their claims to ancestral domain and the right to use the lands on their ancestral domains will not be safeguarded by Muslims.

Claims to ancestral domain are so important because they have recently become a means by which both Muslims and indigenous peoples have attempted to preserve and regain their livelihoods. The stories of the Muslims and the Manobos in the case study from Land Tenure Stories in Central Mindanao are set primarily in the barangay of Kimadzil in the municipality of Carmen in the Province of Cotabato. In the SOCCSKSARGEN region, which includes the municipality of Carmen and which was carved out of the formerly-Muslim Cotabato Province, around $50 \%$ of the people were engaged in agriculture in 2012 ("Regional Profile: SOCCSKSARGEN"). This number is likely too low, considering the fact that many people who formerly engaged in agriculture have been displaced by landlessness and war and have been forced to leave their previous livelihoods. Solving the problems of landlessness and war through genuine agrarian reform would likely result, in the short run, in the return of many people to again engage in agriculture.

In the stories of the Muslims and the Manobos in Land Tenure Stories in Central Mindanao, there is a substantial region of agreement. According to the accounts of both the Muslims and the Manobos, Antig Abang was the first Muslim to settle in the sitio of Kilabaw in the barangay of Kimadzil. He arrived in the 1960s, and the timuay/datu, Pedro Ampalid, very generously granted Antig Abang some land. ${ }^{45}$ Some of Abang's relatives arrived soon after, and Timuay/Datu Ampalid granted them also land in this area. When war erupted close to this area of Mindanao in the 1970s, an officer of the Moro National Liberation Front, Amay Kugaw, approached Timuay/Datu Ampalid in order to ask for help in aiding refugees. Timuay/Datu Ampalid allowed the Muslim refugees to cultivate lands in an area that became known as Sitio Pagalungan, also in the barangay of Kimadzil. Timuay/Datu Ampalid died in 1992, and his son Damasco took on his roles as both Timuay and Datu. The 
Muslim refugees stayed on these lands as well as the lands in Sitio Kilabaw until the early 20oos, when war again displaced them. During an offensive of the Armed Forces of the Philippines, soldiers of the Moro Islamic Liberation Front opened fire on Datu/Timuay Damasco Ampalid, and soon after, in another incident, his nephew was killed. After Muslims left the area of Kilabaw, they have not returned, but some of the displaced Muslims were able to return to the lands in Pagalungan.

The story told by the Muslims and the story told by the Manobos have different emphases, but taken together they reveal the immense impact of the problems of landlessness and war on the peoples of Mindanao. Land is central to the story told by the Manobos, and the gift of land bears two fundamental meanings. The story emphasizes that land means livelihood. Furthermore, the Manobo story emphasizes the way in which the right to land is one strand in a web of social relations. As Timuay Damasco Ampalid narrates,

I had an uncle named Pancho who became a friend of Antig's. They were close friends for a long time. In their closeness they agreed to have one of their children become part of each of their families. And so it happened that Pancho's child, Hemistan, became a part of Antig's family and Kasamela, of Pancho's family. My uncle gave four out of his 10-hectare land to Antig to help him raise his child. Their friendship deepened and they became good leaders. That was how they were able to occupy lands in our territory. My uncle shared and entrusted these lands to them out of friendship. (125)

In Ampalid's account, the land transaction is not a money transaction. The terms that Ampalid uses are primarily terms of human relationships-the land was shared and entrusted, and the families became bonded through intermarriage. The gift of land is further motivated by economic concerns-the land would help Antig Abang to raise his child.

The importance of land to livelihood is reinforced in the next paragraph of Ampalid's account. This importance becomes clear when people in the story are deprived of land:

When the war erupted in the 1970s, Muslims in the Muleta area became targets of the military operations of the $27^{\text {th }}$ Battalion. These operations forced Muslims to flee to safer grounds, leaving their farms unattended. Because of this, then MNLF's area commander Amay Kugaw met with my father. He told my father how the people under his leadership lost their livelihoods due to constant harassment by the Military. He asked my father for assistance to solve his problem. My father offered to Amay Kugaw the area which was evacuated by some of his subjects. He said, "in the meantime that my men has not returned in Pagalungan, your men can stay and work there. But when my subjects return, and your area in Muleta would be peaceful, your men must leave the area." (125)

Kritika Kultura 25 (2015): -141 
Ampalid tells the story in a way that makes explicit the fact that the refugees are farmers: When they flee from the Armed Forces of the Philippines, what they leave are their farms. Because they are farmers, they leave not just their homes but also their livelihood and the fruits of their labor. Ampalid's father does what he can in order to help the refugees. He provides them with land they can work on so they can again earn their livelihood.

The Manobos, in turn, themselves experienced displacement. In Ampalid's narration of the time after the conflict subsided landlesness, and thus the lack of a means for livelihood, becomes a central concern:

In those days, many returning Manobos had no lands on which they could live on. Without lands to till, they were plunged to difficult conditions. Some had almost nothing to eat and had to ask for food from the Muslims who were then benefiting from their lands. My father asked the Muslims to leave the area, but they refused. So my father told one of his aides, "since they refuse to leave, it might be worthwhile to ask the Muslims there to share their income, even if not on a fixed percentage, so that those who returned have something to live on." The Muslims verbally agreed to share their income from harvests. But during harvest time they refused to give share as agreed. When the Manobos insisted on their share, the Moro occupants brandished armalite rifles. With that, we started to fear for our lives." (126)

The bonds that were forged earlier between Pedro Ampalid and Antig Abang were based on trust, the sharing of land, and a concern for the livelihoods of people in the community. In Damasco Ampalid's narration, these bonds are broken. First of all, the promise to vacate the lands is not kept. Ampalid's narration highlights further the breach of trust as the different communities occupy different positions within similar narratives. The Manobos are put into the position previously occupied by Muslims who had been displaced and the Muslims are put into the position of the Manobos, but the Muslims, instead of sharing, threaten the Manobos.

Furthermore, Manobos were forced to enter into very unequal arrangements with the Muslims who occupied their lands:

We realized that the Muslims did not have any intentions of vacating the lands, and that it was not possible to recover our land. Because of these, some of us decided it was better to mortgage lands if we wish to benefit from our rights. Eventually, some of us accepted carabaos as mortgage payment; others agreed to one carabao in exchange for eight to ten hectares of land. Others were left with no option but to accept a carabao as payment because the Muslims would not agree that they just mortgage their land. (126) 
In this passage, the words "accepted" and "agreed" are used in very strange ways insofar as the Manobos were forced into signing documents with very unequal terms. ${ }^{46}$ The solution that the Manobos favored was for the Muslims to vacate the lands. Instead, some Manobos received no benefit from their lands, some people mortgaged their land, and some even sold their land.

In the aftermath of these events, one thing that is clear is that there was a division between the Muslims and the Manobos of these barangays of Carmen concerning what constituted their rights to the land. Muslims would later produce documents of mortgage and sale signed by Manobo mortgagers and sellers (130). ${ }^{47}$ Furthermore, according to Ampalid's narration the relationship between land and armed conflict is one in which Muslims, themselves displaced by armed conflict, in turn attempt to use military means to grab the lands of the Manobos: "They attacked us so that they could take over this place. We can't say they were out to grab our properties; we had none of those, except our lands" (127). In the accounts of the Muslims, on the other hand, the relationship between land and armed conflict is more complicated. The conditions of this particular armed conflict, in which the government of the Philippines uses techniques of counterinsurgency warfare with the support and training of the US military, are major barriers to achieving peace in Mindanao. The conditions of counterinsurgency warfare are barriers to peace not only because of the physical violence they create but also because of the barriers to interpretation that they create.

In contrast to the Manobo story, the Muslim story is not narrated by a single person. The story was generated through two sources: an interview with an officer of the MILF and a focus group discussion that brought together Muslims from among the 186 families who were involved in the land dispute. The focus of the Muslim story is on the displacement of Muslims by war, and in particular by war fought by militias supported by the Armed Forces of the Philippines. In a previous moment, the creation of one militia served as the occasion for bringing Muslims and indigenous peoples together. Later on, the creation of another militia drove the Muslims and indigenous peoples apart.

Kumander Iskak, the MILF officer in Kapalawan Province who was responsible for administering assistance to Moros who were displaced by war, describes this previous moment (124). ${ }^{48}$ Ilaga militias in the early 1970s drove Muslims to flee their homes in other barangays of Carmen and to appeal to Pedro Ampalid and seek refuge in the lands of the Manobos: 
At that time, there was no one who can act as guarantor for the entry of the Moro except Datu Ampalid. People were then still afraid of the presence of the Ilaga. Also at that time, we saw some natives who were among the Ilaga. If you are not accompanied by a native, you cannot guarantee the safety of Muslims. And Datu Pedro, because of his being an authority, wielded influence among the natives. He guaranteed the Maguindanaos' safety. He escorted the second batch of 86 (all from Bgy. Kibayao and Kasapian) Moro families who entered the Manobo territory ${ }^{49}$ (128)

At this time, the Moros were afraid that members of the Aromanon Ilianon Manobo tribe were themselves Ilaga. ${ }^{50}$ Pedro Ampalid, in Iskak's account, acted as a mediator. He was uniquely positioned to act as a mediator because he held the title of both datu and timaway. After the death of Pedro Ampalid, his son Damasco also received the title of datu and played a crucial role in keeping peace between Moro and Manobo people in the area. A certain tension arises, though, between Iskak's and Damasco Ampalid's stories when they recount the period between the arrival of the Muslim refugees and their forced displacement during the war in the early 20oos. Iskak claims that the period was one of harmony and peace, while Damasco recalled the period as one in which Manobos suffered because they could not return to the lands that the Muslims had settled. In other words, Iskak emphasizes the military aspects of the situation, while Damasco emphasizes the economic, and in particular the livelihoods of the Manobos and the Muslims.

The passage of the Moro narrative, in which the transition between the period of peace during the $1980 \mathrm{os}$ and $1990 \mathrm{os}$ and the period of war during the early $2000 \mathrm{~s}$, is split. The beginning of the passage is narrated by Kumander Iskak, who was interviewed by writers of Land Tenure Stories in 2009 at an undisclosed location because, as a member of the MILF, he was a target of the Armed Forces of the Philippines (146 note 9o). The second part of the passage is taken from a focus group discussion conducted a few weeks before the interview with Iskak, and it was held at a public location, the poblacion of the municipality of Carmen (146 note 94):

[Iskak] There were no unresolved disputes between the Moros and the Manobos. We lived in absolute harmony and peace. All of us looked upon Damasco as our datu. He was recognized as an elder. He resolved disputes which were not complicated, not violent, such as marital disputes, and brawls. When a Moro and a Manobo figure in a conflict, Datu Damasco and I were tasked to resolve it.

We used the process of resolving disputes according to tradition and according to the MILF system. At that time, Datu Damasco was not yet elected kagawad [member of the barangay council]. He was a ranking member of the MILF. [Focus group] We join each others' activities and celebrations. There were intermarriages between the two groups. 
There were no segregation in dwellings; Moro and Manobos' houses were built close to each other.

During the all-out-war of 2000, MILF combatants passed by Pagalungan from Muleta on their way to their camp at Kilabaw. This made the Manobos suspect that we sided with the MILF. At that time, there was no chance to explain because of the security condition. We were also afraid to go to the Manobo area because the Manobos were identified with government. Among them were CAFGU members who were targets of MILF men. They believed they fought at the side of government by acting as military guides. $^{51}(128-9)$

In this part of the narrative of the Muslims, the portion that is attributed to Iskak emphasizes the harmonious relations between the Muslims and the Manobos. The portion that is attributed to the focus group begins with confirmation of the story of harmonious relations, but the emphasis shifts to the militarization of the relationship. The account itself presents a barrier to interpretation: the members of the focus group "believed" that the Manobos included Citizen Armed Force Geographical Unit (CAFGU) members. In other words, the members of the focus group could not be certain that the Manobos were collaborating with the Armed Forces of the Philippines, who had launched an offensive against Muslims in Mindanao.

It will be necessary here to go into some depth about the history of the CAFGUs, and the reason why the suspicion of Manobos being CAFGUs would be such a serious matter. The CAFGUs descend from a line of militias that were formed by successive governments of the Philippines since the end of World War II in order to wage counterinsurgency warfare against the Filipino people. ${ }^{52}$ Militias were given the name of $C A F G U$ in 1987 during the regime of Corazon Aquino, ostensibly to consolidate all "auxiliary," non-regular military forces under a single command under the Armed Forces of the Philippines and to comply with the 1987 Philippine Constitution's prohibition on private armies and non-statutory forces (Institute 17-8). However, CAFGUs are currently classified into two types: CAFGU Active Auxiliaries who are directly supervised and paid by the AFP, and Special CAFGU Active Auxiliaries (SCAAs), who are paid by private businesses and local government units. SCAAs are accountable primarily to the companies and local government officials who pay them, and thus they are hard to distinguish from private armies (Institute of Bangsamoro Studies 19).

For many people in the Philippines, the term CAFGU invokes human rights abuses such as torture, murder, extrajudicial killings, rape, looting of property, forced disappearances, and arson. According to the Philippine Commission on Human Rights, in the year 2000, 853 cases of murder, execution, disappearances, 
and illegal arrest were filed against 1,017 CAFGUs. The Ecumenical Movement for Justice and Peace recorded around 20,000 cases of human rights violations attributable to CAFGUs. After declining in the 1990s, the number of CAFGUs has risen dramatically since 2000. In 2007, there were about 53,000 CAFGUs, while the number of active duty members of the Armed Forces of the Philippines was about 120,000 (Institute of Bangsamoro Studies 24-25).

In the narrative of the focus group, the alleged-CAFGUs are suspected of being "guides." This suspicion stands as a barrier towards interpreting the statement of the focus group. Within the context of the Philippines, the human rights violations of the Ilagas and the CAFGUs would shadow any reference to them. The barrier to interpretation also stands as a barrier to peace, and the barrier to interpretation exists because of the militarization of Mindanao wrought by the Government of the Republic of the Philippines and its armed wings, the Armed Forces of the Philippines and the CAFGUs. According to the editors of Land Tenure Stories, for the conflict to be resolved the Moros believe that justice must be in place. Justice would be achieved when the problem of mutual accusation, i.e. Moros siding with the MILF and Manobos becoming CAFGUs, is clarified and the search for solutions to achieve peace is undertaken (129). This situation exists because the MILF was targeted by the government of the Philippines, making it impossible for MILF members to reveal their affiliation. On the other side, the CAFGUs, unlike regular members of the AFP, are not readily identifiable, and thus they are even less accountable than regular personnel of the AFP. Furthermore, it is not clear whether the CAFGUs were under the command of the AFP, a local politician, or a private corporation..$^{53}$

At the time of writing of Land Tenure Stories, the conflict between the Muslims and the Manobos was unresolved. However, the resolution of the conflict cannot arise simply from MILF forces capitulating and laying down their arms. For the Muslims, a resolution of the conflict would require the negotiators to address their lack of livelihood. The Muslims who were displaced during the all-out war of the AFP in 2000 became dependent on their families who lived elsewhere, and where possible they hired themselves out to farming (124). They expressed a desire to return to the lands they previously occupied, and this desire was urgent. They agreed to attend the focus group discussion because they believed that it would speed up the process of resolution (130). However, the negotiations were very difficult because Manobos who had previously vacated the lands might have returned to work on them.

The resolution of the conflict cannot occur unless much larger issues, that affect all of the peoples of the Philippine archipelago, are addressed. A just and lasting peace would address the issue of the lack of livelihood, which, as the narrative of 
the Manobo Timuay Pedro Ampalid suggests, must address issues around land and landlessness. However, the militarized response to the issues around land and landlessness pursued by the Government of the Republic of the Philippines, instead of solving the problems, creates deadly conflicts and the displacement of peoples. Because of the economic crisis in the Philippines the stipend paid to CAFGUs attracts recruits, who join primarily because of their lack of other forms of livelihood (Institute of Bangsamoro Studies 40). However, although the recruitment of CAFGUs divides communities and creates conditions for deadly conflicts, it does not create livelihoods for the people. One of the major reasons why CAFGUs are recruited is because the Philippine state cannot afford the militarized solution to conflict. CAFGUs are paid much less than regular AFP soldiers and do not receive benefits equivalent to regular AFP soldiers (Institute of Bangsamoro Studies 18). A statement by a CAFGU on the island of Basilan, a heavily militarized island just south of Zamboanga, further shows the inadequacy of the stipend in solving problems around the lack of livelihoods:

I look forward to that day the CAFGUs' allowance will be increased and released regularly on time. Nowadays, our families face financial hardship. Our small allowance, which is not enough for our daily needs, is delayed for three months. My wife, [a fish vendor in the market], borrowed money as capital from a money-lender with a high interest. Her capital for vending fish went instead to our daily needs. (Institute of Bangsamoro Studies 41)

Clearly, in this case, the needs of CAFGUs are not prioritized by the government of the Philippines, and it is likely that CAFGUs, even when they receive their pay, still suffer from financial hardship. The story suggests that, even for the CAFGUs, the militarized response to people's movements is not sustainable. ${ }^{54}$

The Philippine state has played a significant role in exacerbating the conflict between the Muslims and the Manobos of Barangay Kimadzil. According to Eddie Quitoriano, most male members of the Manobo community in Kimadzil joined the CAFGU, and they were deployed in another part of Carmen as part of the AFP operations in this part of Mindanao ("Impact" 21). Meanwhile, state efforts to aid the Manobos have been inadequate, and NGOs such as the Kadtuntaya Foundation and Tabang Mindanao have undertaken relief operations in Carmen to provide farm animals such as goats, pigs, and carabaos (Candelaria et al. 98). State support for Muslim refugees has also been inadequate, and the MILF seems to be the only state-like entity that provided the families aid. Furthermore, the current Philippine government institutions for implementing the redistribution of land have also been inadequate and might even have caused harm. Also according to Quitoriano, legal title to Aromanon Manobo lands have been transferred to outsiders through the Comprehensive Agrarian Reform Program (CARP), the heavily-criticized land 
reform law of 1988 ("Land" 17). It is curious that in the Muslims' account of the events in Kimadzil they made no mention of attempting to return to the lands that the Ilaga forced them to vacate, lands in nearby barangays as well as the provinces of Maguindanao and Sultan Kudurat, and it does not seem that the Philippine state has provided a way for them to reclaim their lands (Kadtuntaya 128). Meanwhile, Aromanon Manobo claims to ancestral domain through IPRA, like many ancestral domain claims of indigenous peoples in the Philippines, are held up in processing (Lacorte).

The stories told by the Muslims and the Manobos of the barangays of Carmen provide necessary perspective for the literary texts of Bulosan, Jubaira, Lao, and other writers whose works have touched on Mindanao and Sulu. This perspective is particularly necessary for those who desire a just and lasting peace in the Philippine archipelago. In order to sustain peace the livelihoods of the peoples of Mindanao must be the primary concern, and the livelihoods of the overwhelming majority of the peoples of Mindanao are tied to the land. The Government of the Republic of the Philippines has repeatedly shown, not only with regard to Muslims and indigenous peoples but also with regard to the overwhelming majority of Christian Filipinos, that the profits of multinational corporations, the strategic interests of the US in the Asia-Pacific region, and the fortunes of the handful of elite comprador and landlord families are its primary concerns, with little concern for the peoples of the Philippine archipelago.

At the time of the writing of this monograph, the Government of the Republic of the Philippines and the Moro Islamic Liberation Front are apparently nearing a peace agreement that would establish a Bangsamoro region within the borders governed by the Philippine state. In 2012, the Philippine Government and the MILF reached a framework agreement on the creation of a Bangsamoro political entity that would replace the Autonomous Region of Muslim Mindanao (ARMM), which was created in 1989 through negotiations between the Philippine Government and the MNLF, and in 2013, the Philippine Government and the MILF reached a comprehensive peace agreement. The Bangsamoro region would potentially include not just Lanao del Sur, most of Maguindanao, and most of the Sulu archipelago, which are already governed by the ARMM, but also Cotabato City, predominantly Muslim municipalities of Lanao del Norte, and barangays in North Cotabato (GPH-MILF 6). On September 10, 2014, the Bangsamoro Basic Law (BBL), which would establish a legal framework for a Bangsamoro territory with certain powers reserved for the Government of the Republic of the Philippines, was submitted for approval to the Philippine Congress. 
Currently Barangay Kimadzil is not included in the proposed Bangsamoro region, although two other barangays in Carmen are included (Rodil, "Indigenous"). Aromanon Manobo leaders specifically requested from the Philippine Congress in June of 2014 that their lands not be included in the Bangsamoro autonomous political entity. Instead, Manobo leaders requested that Congress direct the National Commission on Indigenous Peoples to fast-track the delineation and titling of the ancestral domains of their peoples and the other indigenous peoples who live adjacent to the proposed Bangsamoro territories (Lacorte).

Although very few Aromanon Manobos live in the proposed Bangsamoro region, large groups of indigenous peoples in the province of Maguindanao, to the west of Carmen, live near the center of the Bangsamoro region. The largest of these groups is the Tedurays, with a population of 57,296 in Maguindanao according to the 2000 census (Rodil, "Indigenous"). The total population of non-Moro indigenous peoples within the proposed Bangsamoro territory is estimated at 122,980 (Tauli-Corpuz, "BBL"). Indigenous peoples have had to struggle to participate in the process for creating the Bangsamoro territory and to be acknowledged in the proposals for the Bangsamoro Basic Law, and these struggles have won some limited success. Moro leaders have responded positively to indigenous leaders who have referenced a pact between common ancestors of the Moros and Lumads, the Mamalu-Tabunaway pact, concerning the delineation of territories for peaceful coexistence. Furthermore, two lumads were appointed to the transitional Bangsamoro Transition Commission, which is tasked to draft the Bangsamoro Basic Law (Paredes 175).

A UN Special Rapporteur on the Rights of Indigenous Peoples, Victoria Tauli-Corpuz, has acknowledged the effects of the efforts of indigenous peoples on the current draft of the BBL being considered in the Philippine House of Representatives. The document specifically acknowledges that indigenous peoples are not subsumed within a Moro identity, a response to the demands of indigenous peoples to maintain their own identities. Unlike previous drafts, the draft as of May 26, 2015 uses the term "non-Moro Indigenous Peoples" in several places in the BBL, including the preamble. Furthermore, Section 9 Article IV is entitled "Declaration on the Rights of Non-Moro Indigenous Peoples."

However, the UN Special Rapporteur also states that the document is somewhat incoherent insofar as Article 11 states that all non-Moro Indigenous Peoples are Bangsamoro, which runs counter to the concern that the identities of indigenous peoples need to be acknowledged ("BBL"). Tauli-Corpuz also raises concerns about whether the proposed Bangsamoro region would also allow indigenous peoples to pursue claims to ancestral domains. Within the Autonomous Region of Muslim Mindanao no ancestral domain title has ever been issued because the 
ARMM has not implemented IPRA (Paredes 173). In initial drafts of the BBL, there was no reference to IPRA, leading many indigenous people to raise concerns that they will not be able to title their ancestral domains. In response, in the May 26 House draft of the BBL, there is a reference to IPRA and an article that states that the Bangsamoro and Philippine governments will cooperate and coordinate through existing national laws to create policies for the identification, delineation, and titling of ancestral domains. However, the article does not clearly state that the objective of these laws will be to recognize and protect the rights of non-Moro indigenous peoples that are enshrined in IPRA and the UN Declaration on the Rights of Indigenous Peoples. Furthermore, in another article the Bangsamoro government is given exclusive power to recognize traditional possession of lands and resources by indigenous cultural communities "subject to judicial affirmation," but there is no clarity about what body will issue the judicial affirmation. In IPRA, there is no reference to judicial affirmation, which would not be appropriate to Native Title, which refers to pre-conquest concepts of land ownership before the colonial declaration that the lands were "public" lands subject to the settlers' courts (Tauli-Corpuz, "Non-Moro").

There are many hopes tied to the peace process for the people of the Philippines, and this process is so important because it is an occasion to address historical wrongs and establish justice. It would be a great tragedy if the final version of the $\mathrm{BBL}$ results in the continued or even intensified oppression of indigenous peoples and Muslim and Christian farmers, workers, and refugees of the proposed Bangsamoro region. It remains to be seen whether the BBL and the state that it would create will allow the peoples of Mindanao and Sulu to regain, preserve, and develop their livelihoods and put an end to the cycles of war, dispossession, and forced migration. If the BBL passes in its current form, those who would stand in solidarity with indigenous peoples must be vigilant so that the rights of indigenous peoples are upheld; those who would stand in solidarity with the overwhelming majority of Moros, who rely on land for their livelihoods, must also monitor the situation carefully because there is no provision in the BBL for land reform.

On the question of the possibility of solidarity between Filipino Americans and the peoples of Mindanao, it will be helpful to return to the Forum Kritika on Carlos Bulosan and becoming Filipino. John Streamas' contribution to the forum provides comments on the reception of America is in the Heart among Filipino American students at Washington State University. Most of the Filipino American students are from an urban area, Seattle, but the main campus of Washington State University (WSU) is situated in a rural area in which the overwhelming majority of people are white. Apparently, the Filipino American Students Association (FASA) plays an 
important part in the educational experiences of Filipino American students at WSU. The presence of a Filipino American student organization certainly plays a part in the reception to America Is in the Heart that Streamas records for his introductory literature courses:

Most of my Filipino American students feel close ties to the Philippines, whether or not they often visit family there, and the significance of the book's first part is not lost to them, even if they feel closer identifications with its subsequent parts. They know the history of colonization, and they have seen film documentaries about contemporary issues such as the exploitation and violence against overseas domestic workers; and, better than most other Asian American students, they know the historical ties between past and present problems. (214-215)

In contrast to many readers, including literary scholars in the US, many of the Filipino American students see the importance of the book's first part, most of which is set in rural parts of the southern Ilocano region. Streamas notes, though, that as a result of neoliberal reforms, the histories of people of color in the US, including Filipinos, are increasingly left out of the kindergarten-12th grade curriculum in the state of Washington. Recently, according to his assessment, FASA has lost much of its activist and historical focus.

Nevertheless, there is still a strong activist current in the US that must act in the present based on knowledge of the actual histories of the Philippines and the US. In a note, Streamas mentions Stephen Bishcoff, Associate Director of Multicultural Student Services at his university, who tells students "that many of the experiences [of Part I of America is in the Heart] are still relevant today."

Hopefully this relevance will be further articulated in terms of the continuing struggles over land and livelihoods that many Filipinos experience today.

Peoples of Mindanao and Filipino Americans have recently accelerated efforts to build bridges, especially since Tropical Storm Sendong and Typhoon Pablo devastated large parts of Mindanao in 2011 and 2012. Large numbers of Filipino Americans organized and contributed to disaster relief events in the US, and significant numbers helped to organize and participate in medical and relief missions. Furthermore, it is becoming clear to increasing numbers of Filipino Americans that the disastrous effects of climate events in the Philippines are intensified by corruption, militarization, and the neglect with which the Philippine government treats the overwhelming majority of Filipinos. Groups based in the US such as the National Alliance for Filipino Concerns (NAFCON) are calling for and participating in grassroots efforts to enact environmental justice and sustainability in the Philippines, and NAFCON is actively partnering with 
networks such as BALSA Mindanao and Salugpongan International. The Save Our Schools campaign of Salugpongan International is an attempt to safeguard Lumad schools and educational centers, many built in the aftermath of Pablo, from the militarization wrought by the Armed Forces of the Philippines and its sponsors in the US military. Lumad communities have established 146 alternative schools and programs, but this is not nearly enough because nine out of ten Lumad children have no access to formal education ("Infographic"). The response of the Armed Forces of the Philippines has been to attack these schools, with 214 reported cases of military attacks (Romero).

On relations between Filipino Americans and Muslims in the Philippines, there is much less clarity. Most of this monograph is focused on narratives written by Muslims, but there is still much work to be done so that Filipino Americans will begin to both understand their relationships to Muslims in the Philippines and to build concrete connections with Muslim peoples. Perhaps one of the tasks for predominantly Christian Filipino American organizations is to make it a priority to build more connections with Muslim Filipinos in the southern Philippines as well as Muslim Filipinos who have been displaced and who have migrated to the Visayas, Luzon, and overseas. Such relationships are being formed. Peoples Community Organization for Reform and Empowerment (People's CORE), an alliance of organizations in the US, has partnered with Moro People's CORE in North Cotabato, a group that has programs on human rights and peace advocacy, farmers' livelihood and development, cultural arts enhancement, education and literacy, and environmental justice and advocacy. Furthermore, in response to the Mamasapano Massacre of January 2015, in which a US-instigated operation in territory controlled by the MILF resulted in the deaths of several civilians and 44 members of a special unit of the Philippine National Police, a NAFCON statement includes the following words by Potri Ranka Manis, a Maranao Bai Labi (a title of nobility) and a founding member of Kinding Sindaw, a Maranao-based member organization of NAFCON:

The divide and rule tactics using north against south, Christian vs Muslims, is an old scheme that has been used to divide Filipinos. How can the Philippine government who signed a ceasefire agreement send its own police forces to be sacrificial lambs? The scripted violation of the peace process shows who controls the Philippine government officials; this is a mere act to reinforce the rationale for foreign military to continue staying in the Philippines to train and protect its citizens, when in reality the U.S. military is there to protect the interests of the American elite. It's time to unite and to assert our rights for self-determination. (NAFCON)

Manis' statement refers to the continuing imperialist control that the US exerts over the Philippine government, and a basis for unity between most Christian 
Filipinos, indigenous peoples, and Muslims in the Philippines is a common struggle against US imperialism. Additionally, a basis for unity is an economic struggle for livelihood, which for many people in the Philippines is a struggle for land. 


\section{Notes}

1. This monograph uses a definition of settler colonialism based on David Lloyd and Laura Pulido's formulation: "Settler colonialism is the practice of conquering land and then populating it with the victorious people, the settlers" (796). This definition is currently being elaborated in attempts to build solidarity between people in the US and people in Palestine. Recently several US academic formations, including the American Studies Association, the Association for Asian American Studies, and the Critical Filipina and Filipino Studies Collective, have issued statements in support of the Palestinian people.

A definition proposed by Candace Fujikane for the term settler colonialism in Hawai'i might illuminate some aspects of the situation in Mindanao: "Asian settler colonialism refers to the present participation of all Asian Americans in Hawai'i in US settler colonialism through different kinds of settler practices, ranging from colonial administration to the routines of everyday life" (Fujikane 191-2). The position of settler colonist in Mindanao through the US colonial period and up to the early decades of the Republic of the Philippines was occupied primarily by Christian Filipinos. However, as Patricio Abinales has outlined, some Muslims have been able to negotiate positions for themselves as elected officials and high-ranking bureaucrats in the Philippine state and the Autonomous Region of Muslim Mindanao. Furthermore, the dispossession of so many Muslims since the 1970 os has lead to increasing instances of conflict between landless Muslims and indigenous peoples over land. A later part of this monograph will be focused on a specific conflict in which landless Muslim settlers attempt to dispossess a group of indigenous people from their ancestral domain.

The reference to Hawai'i brings up another possible point of comparison between Hawai'i and Mindanao, but to a part of Mindanao that has historically had fewer Muslims and more indigenous peoples. During the US colonial period settlers from the US established abaca plantations in Davao in southeastern Mindanao, but a large number of migrants and settlers from Japan were much more successful in agricultural endeavors (see Abinales 74-86). It would be important, though, to consider more carefully the effects of this settlement on the indigenous peoples of Davao and their responses to the settler incursions.

2. John Streamas documents the problems that literary critics have encountered in identifying the genre to which America is in the Heart belongs. I will call the book a novel, but I agree with E. San Juan Jr's assertion that it is a popular front allegory.

3. America is in the Heart is often included in the syllabi of American Studies, Labor Studies, and Asian American Studies classes in the US. The novel is quoted extensively in the most often-used textbook of Asian American History, 
Ronald Takaki's Strangers from a Different Shore. The only novel in English among those written by Filipino writers that can rival America is in the Heart's circulation is Jessica Hagedorn's Dogeaters.

4. Macario's story is largely based on the story of Bulosan's brother Aurelio. Aurelio was born in November 1904 and after graduating from high school he taught first in Pangasinan before being transferred to Mindanao. He traveled to the US in 1929 with a student visa. Unfortunately, Aurelio in this interview does not state exactly where in Mindanao he was located (Chow 156).

5. Carlos Bulosan's claim in America is in the Heart that the Moros were "not entirely pacified" is perhaps a reference to revolts against the disarmament of village leaders, the imposition of a poll tax, and compulsory education in the province of Lanao during the 1920s, which his brother Aurelio might have been aware of due to his presence in Mindanao as a teacher during the $1920 \mathrm{~s}$ (Kawashima 140).

6. As we will see later in this monograph, one of the effects of US colonial rule on Mindanao and Sulu would be the degradation in the status of community leaders who traditionally preserved the land tenure of peasant families and who settled conflicts within the community. The degradation in the status of community leaders would thus facilitate the imposition of a legal system that would sanction the dispossession of Muslim and indigenous communities by outsiders through the privatization of land and the introduction of a foreign process for acquiring titles to land.

7. The effort of building solidarity between workers in the US and peasants in the Philippines is arguably an extension of the efforts to build solidarity within the Philippines between workers and peasants that found expression in actual alliances formed on the island of Luzon in the late 1930s. The size of this working class was limited by the lack of industrial development in the Philippines, which was prevented by the US colonial regime.

8. The new Philippine government in the early 1950 s attempted to solve the problem of landlessness in Luzon and the Visayas by settling peasants and soldiers from these regions in Mindanao. This program, however, was not new, because the US colonial regime and the previous Commonwealth government of the Philippines had attempted to quell peasant revolts in Luzon and Visayas by relocating peasants to Mindanao since the early 1910 .

9. There are several theses on Jubaira's works that I have not been able to read: "Isolation in the short stories of Ibrahim A. Jubaira" by Amor Babiera (San Carlos 1967), "An analytical study on selected short stories of Ibrahim A. Jubaira and their educational implications" by Luzviminda Cagas (Ateneo de Davao 1973), 
and "Reflections of Muslim culture and human values in Ibrahim A. Jubaira's short stories, A Canto Of Summer and other stories" by Linda Orduna (Saint Louis University 1980)

10. I will assume in this monograph that the story was written in the late-1930s or early 1940s, and that it was published in 1941. Pacita Habana, in her bibliographical note on Ibrahim Jubaira, gives a publication date for "Blue Blood" in 1957 in the anthology Best Philippine Love Stories. I have personally not been able to read issues of Graphic magazine from this period. Leopoldo Yabes, in the anthology Philippine Short Stories1941-1955, gives the publication date of "Blue Blood" as August 28, 1941, in Graphic magazine. Habana does list other stories that were published by Jubaira in the magazine Graphic in 1939 and 1940.

11. I do not wish to give the impression that Sulu was isolated and did not engage in trade prior to US rule. This, of course, is far from the truth. However, Sulu's status as an entrepot in Southeast Asia declined during the second half of the $19^{\text {th }}$ century as Spain began to attack Sulu and Sulu's shipping with steampowered naval vessels.

12. For the purposes of analysis, I will define a feudal economy as one that is based primarily on agriculture, in which there is contention between peasant producers and noble landowners over the fruits of agricultural production. Most production is directly consumed by the peasant producers, with a surplus extracted by the landowners. A minor part of this surplus is used to engage in commerce. In the semi-colonial/semi-feudal economy, commerce expands and more of the peasant production is directed towards trade. In a capitalist economy, like the one depicted in the US in America is in the Heart, relatively few of the people would continue to use most of their produce for their own consumption; instead, farmworkers would work for wages in order to purchase their needs. One of the reservations in referring to the agrarian economy as feudal arises because the destruction of the authority of the noble landowners in Mindanao and Sulu resulted in a degradation also in the status of many of the peasant producers.

13. Panglima is the title of a noble below the rank of Datu who performs administrative tasks for a datu.

14. The term "native" appears in the following sentence, which is part of the description of the marriage of Dayang-Dayang: "Half-clad natives kindled [coconut leaves] over the cooking fire. Some pounded rice for cakes. And their brown glossy bodies sweated profusely" (10). The term is, in one respect, a holdover from the language of US and British colonization projects. In another respect, though, it maps onto the specific situation of Sulu. The three major 
states of the Mindanao/Sulu region all participated in a slave trade in which Christians and indigenous peoples were enslaved. See the story of Kumander Iskak later in this monograph for a more recent use of the term. It is important to note, though, that the leaders of many indigenous tribes on Mindanao embraced the term lumad, the Bisayan word for "native," in the late $1980 \mathrm{os}$ in order to unify themselves.

15. Jaafar omits a crucial piece of information: the source of his initial capital. This is a convention of much capitalist storytelling, which denies the violence with which capital was originally accumulated.

16. The character of pre-capitalist modes of production in the Philippines needs elaboration beyond the scope of this monograph. The term "feudal" in the Philippines is tremendously complicated insofar as those who have occupied the position of landlord have been so varied. In the north there would be a combination of Spanish, Chinese, and Malay influence on the meaning of feudalism. In the south there is the influence not just of Islam but also the different places from which Muslim influence emanated such as Arabia, India, and other parts of maritime Southeast Asia.

17. It is possible that Jubaira refers in this passage specifically to the 1927 incident in which Datu Tahil of Patikul refused to acknowledge the authority of US colonial government officials. The location of the Astana in "Blue Blood" is Patikul, a municipality close to Jolo. Datu Tahil lead a popular movement to abolish the land tax, contest compulsory attendance of children at school, gain the privilege to bear arms, and to remove certain provincial officials. He built and defended a fort, but government forces sieged and then overran it. He was captured and initially sentenced to serve ten years imprisonment and pay a fine of $\$ 10,000$ (People).

18. The most brutal of the US military operations in Sulu, the Battle of Bud Dajo in 1906 in which US forces killed all but six of the 800-1,00o people who had fortified a position on the mountain of Bud Dajo, was precipitated by the refusal of the people to pay taxes to the US military government. The New York Times published an article shortly after the battle with the headline "Women and Children Killed in Moro Battle." A second battle would occur on Bud Dajo in 1911. See Michael Salman, The Embarrassment of Slavery, for an account of the discourses of US military officers regarding slavery in Sulu and Mindanao. It should be noted that the discourses of US military officers regarding slavery, and the actions of the occupation regime, were clearly not motivated by any desire to improve the well-being of those enslaved; rather, the discourse of slavery served as the justification for the violent seizure of sovereignty and the eradication of the state that opposed the US. 
19. The term moro is a remnant of the Spanish wars against the Muslims of Mindanao and Sulu, but the US colonial administration used the term to name the Muslim regions of the Philippines as well as the wars that the US military fought against peoples of these regions.

20. This quotation, including the parenthetical additions to the text, is taken directly from the thesis of Marjanie Macasalong. Macasalong acknowledged the help of Ustaz Abdulwahab Amerol in retrieving a photocopy of the document from the Franklin D. Roosevelt presidential library. A scanned copy of this document should be more accessible. The number of signatories is inconsistent between commentators, ranging from 100-200. This number might be verified by examining the original document.

21. It is possible to regard the Dansalan Declaration, in its protest against political repression, as an early articulation of anti-fascism in the 1930 .

22. Portia Lei Braza, a blogger in Iligan City, has posted the text as well as some details about the circulation of the letter. According to the blog post the letter was left with a US military officer, Lt. Col. Wallace C. Philoon, who then forwarded it to the commanding general of the Philippine Department.

23. The prison of San Ramon near Zamboanga is where Dayang-Dayang's husband is incarcerated.

24. See Kawashima Midori, "Transformations of Concepts of Homeland and People Among Philippine Muslims," for a catalog of the petitions circulated by Moro leaders. Midori pays careful attention to the fact that these petitions were written in vernacular languages and then translated into English. Midori elsewhere has written in detail about the political context in Lanao that gave rise to a petition shortly before the Dansalan Declaration was written. "Commentary on a Maranao Petition." This petition had around 30 signatories, and Midori traces the outlines of the organization of religious leaders and educators who produced the document. However, apparently, the political situation changed significantly between 1934 and 1935 . The Dansalan Declaration, in contrast to the 1934 petition, invokes a Moro political identity that extends across Mindanao and Sulu.

25. The Dansalan Declaration is named for the place in which it was signed, which was the capital of the province of Lanao during the US colonial period. In 1956 Dansalan would be renamed Marawi City, the major city of Lanao Del Sur today.

26. To provide a sense of scale for this migration, the US Census of 1960 counted 176,310 Filipinos in the US (US Census Bureau). During the huge spike in migration to Mindanao between 1948 and 1960, the US maintained a quota 
of around 100 immigrants from the Philippines. A more thorough account of the early- $2 \mathrm{O}^{\text {th }}$ century migration to Lanao would consider the problem of landlessness in the Visayas, from which most of the settlers departed.

27. See, for example, "Unveiling the Law" and "The Debutante is a Muslim Princess" in Inquirer.net and "This Ali Fights for Muslim Women" in Newsblaze.

28. According to the web site of the Women's Islamic Initiative in Spirituality and Equality Lao has had some involvement with Nisa, a network of Muslim women's rights advocates in Muslim Mindanao. According to one of its members, Nisa "works on gender issues in the context of discourse in Islamic legal theory, vis-a-vis women's human rights and gender, and supports grassroots initiatives through its member organizations. Nisa is involved in raising the level of awareness of open-minded Muslim women and men as regards Muslim women's rights. It achieves this goal through its programs on women empowerment; policy reform; research and advocacy; protection and promotion of women's rights, including litigation; and women in peace and security" ("Laisa Masuhud Alamia").

29. In her report on the UN Convention on the Elimination of All Forms of Discrimination Against Women, Lao wrote extensively about early marriages. It should be noted that under the Code of Muslim Personal Laws in the Philippines a wife may divorce a husband if certain conditions are met. Christian women in the Philippines are not able to divorce their husbands.

30. Rido or ridu is a Maranao, Iranun, and Maguindanaon term. These are the three largest Muslim ethno-linguistic groups on Mindanao. According to Wilfredo Torres, this term was in existence prior to the adoption of Islam by these groups (12).

31. Matuan's inventory of ridos during the period from 1994 to 2004 documented only one case in which a woman was the assailant. Of the victims, 11 were women and 189 were men.

32. Lao has herself written on the myth that Muslims are violent (" 12 More Myths about Islam").

33. The region around Lake Lanao in northwestern Mindanao to the east of the Zamboanga peninsula.

34. Kalilang refers here to festivities around the kalawi. 
35. In 2012 in the ARMM as a whole, which includes the province that contains the Ranao, over $70 \%$ of the people engage in agricultural employment (Philippine Statistics Authority, "Regional Profile: Autonomous Region of Muslim Mindanao")

36. Land grabbing in Mindanao was facilitated by the titling process for homesteaders. Homesteaders from Luzon and the Visayas were often awarded titles from Manila, while Muslims who already lived on the land had to go through the titling process themselves without support. In 1913, Christian homesteaders were entitled to 16 hectares, while Muslims who went through the homesteading process were entitled to only 8. In 1919, a new homesteading law entitled Christians to 24 hectares, with Muslims who went through the titling process receiving only 10 (Abreu 22). The Philippine government initially allowed corporations to control up to 1024 hectares, but US corporations such as Del Monte were able to circumvent the law and establish huge plantations on Mindanao ("History of Dole").

37. 40 acres - the area of a very large farm-is equivalent to just over 16 hectares.

38. T.J.S. George, quoted in Busran-Lao (9).

39. Rufa Cagoco-Guiam has written on the efforts of internally displaced peoples in Mindanao to survive (see"Gender and Livelihoods among Internally Displaced Persons in Mindanao, Philippines"). Regarding polygamous marriages, it would be important to consult women who are in these marriages.

40. According to Wernstedt and Simpkins, the overwhelming bulk of the immigration to Cotabato during this period occurred after World War II, between 1945 and the census enumerations of 1948 (88).

41. The following provinces and cities were carved out of the center of what was once the Maguindanao Sultanate in South-Central Mindanao: South Cotabato, North Cotabato, Maguindanao, Sultan Kudarat, Sarangani, and Cotabato City and General Santos City. The province of Cotabato was created in 1914, then partitioned into North and South Cotabato in 1966, and North Cotabato was further partitioned into Maguindanao, North Cotabato, and Sultan Kudarat in 1973. An act of the Philippine National Assembly in 1983 renamed North Cotabato to Cotabato (Cotabato Province Government).

42. Land Tenure Stories is an immensely complex volume. Several agencies based in three different cities were involved in publishing it, the state of war made it necessary for some people involved in its production to exercise discretion, and the technical team included an advisory committee, a panel of reviewers, seven writers, two researchers, nine research assistants, three technical coordinators, 
and two editors. I can only hope that such a large collective effort aspired towards creating conditions for a just and lasting peace in Mindanao.

43. The group that would become the MILF originally split from the MNLF in 1977. The MILF was launched in 1984, and it became the primary target of attacks from the government of the Philippines. The MILF and the Government of the Republic of the Philippines agreed to a cease fire in 1997, but this was broken with the "all-out" war waged by the AFP in 200o. Peace talks and a cease-fire resumed in 2001, and after a flare-up of war in 2008 a framework agreement between the MILF and the GRP was reached in 2012. There is a regional and ethno-linguistic difference between the bases of support of the MNLF and the MILF. The MNLF is strongest among the Tausug and Sama ethnic groups on the Sulu archipelago, while the MILF is strongest among the Maguindanao and the Maranao in Central Mindanao (Rivera 42).

44. Although the mechanism exists for indigenous peoples to claim their ancestral domains, and some claims have been approved, the process is far from perfect because the NCIP, the agency that processes the claims, is severely underresourced. Currently, only one claim per province per year can be in process, and the delineation and processing of claims can take several years (Paredes 171-2). Some indigenous peoples groups have criticized IPRA and NCIP. According to Giovanni Reyes of KASAPI (Coalition of Indigenous Groups in the Philippines) the NCIP by 2010 had issued 156 Certificates of Ancestral Domain covering 4.3 million of the 7.5 million hectares of ancestral domain. However, only about 937,000 hectares had been titled. In comparison, as of 2010 the NCIP had issued 320 certifications for mining, logging, and dams (Salamat).

45. "Datu" is a Muslim title, and "Timuay" is a Manobo title. Traditionally, the datu and the timuay held positions of leadership in Muslim and Manobo communities. Pedro Ampalid was a recognized leader among both the Muslims and the Manobos. It is important to point out that Pedro Ampalid's son, Damasco, does not refer to himself as a datu.

46. It is possible that the words "accept" and "agree" have lost nuance in translation.

47. The genealogies for concepts of land tenure among Muslims in Mindanao are surely very complicated. I imagine that they involve complex interactions between Sharia, indigenous understandings of land rights, and Philippine law, which itself draws on US and Spanish legal concepts. In terms of this monograph the examples of the thoughts of Muslims on land and land tenure diverge sharply. The stakes of this question are particularly high now because both indigenous peoples and Muslims in the Philippines are articulating land claims in terms of "ancestral domain." 
48. Kumander, a title for officers within the MILF, should be pronounced similarly to the English word commander.

49. The interview might have a slight mistranscription. According to the 2010 census in the municipality of Carmen there is a barangay named Nasapian. The census lists the spelling of Kibayao as Kib-Ayao.

50. The use of the term "native" here is reminiscent of Jubaira's usage of the term. It is possible that the term is a translation of lumad, which has been embraced as a name by peoples from many indigenous tribes in Mindanao.

51. There is an opaque but complex set of mediations between the Muslim families and the text that appears in Land Tenure Stories. Writers of the volume decided to place, apparently seamlessly, the narration of Iskak together with statements at the focus group meeting. It is unclear whether Iskak was at the focus group meeting, and it is not clear who are the referents for the pronoun "we." The writers of the report surely faced challenges in transcribing the focus group discussion.

52. The historical genealogy of this tactic of counterinsurgents in the Philippines is traceable to the Philippine American War, in which US forces enlisted groups such as the Macabebe scouts who lead US forces to Emilio Aguinaldo. Since Philippine independence the primary target of the US-backed armed forces of the Philippines has been popular movements of peasants, workers, and students, as well as Muslims across class lines.

53. According to a USAID and Asia Foundation-supported summary, Bisaya settlers who controlled municipal and barangay governments in North Cotabato and the neighboring province of Bukidnon convinced Manobos to enlist as CAFGUs and CVOs (another paramilitary formation that supports the AFP) (Alim et al).

54. This excerpt of the interview with the CAFGU provides a glimpse of the gendered experiences of war. It is not a viable option for most Muslim and Christian women to join the CAFGU in order to supplement their families' incomes. Rufa Cagoco-Guiam has written on the gendered effects of displacement due to war, and especially the important roles of women in seeking livelihoods for their families (seeRufa Cagoco-Guiam, "Gender and Livelihoods among Internally Displaced Persons in Mindanao, Philippines"). In Guiam's report, internally displaced women receive almost no support from the state in their livelihoodseeking activities. 


\section{Works Cited}

Abinales, Patricio. Making Mindanao: Cotabato and Davao in the Formation of the Philippine Nation State. Quezon City: Ateneo, 20oo. Print.

Abreu, Lualhati M. "Colonialism and Resistance: A Historical Perspective." The Moro Reader: History and Contemporary Struggles of the Bangsamoro People. Ed. Bobby Tuazon. Quezon City: CenPEG Books, 20o8. Kalinaw.org. Web. 7 Sept. 2014.

Alim, Guiamel, Ismael Kulat, and Jose Bulao. "Understanding Rido in North Cotabato and Bukidnon for Creative Conflict Management and Resolution." Consortium of Bangsamoro Civil Society, June 2005. Web. 15 July 2015.

Alquizola, Marilyn C. and Lane Ryo Hirabayashi. "Carlos Bulosan on Writing: The Role of Letters." Kritika Kultura 23 (Aug. 2014): 168-188. Web. 2 July 2015.

Amorao, Amanda Solomon. “The Manong's 'Songs of Love': Gendered and Sexualized Dimensions of Carlos Bulosan's Literature and Labor Activism." Kritika Kultura 23 (Aug. 2014): 221-235. Web. 2 July 2015.

Barry, Coeli. "Blue Blood of the Big Astana-Ibrahim Jubaira." Kyoto Review of Southeast Asia 5 (March 2004). Web. 14 Sept. 2014.

Bentley, G. Carter. "Mohamad Ali Dimaporo: A Modern Maranao Datu." An Anarchy of Families: State and Family in the Philippines. Ed. Alfred W. McCoy. Madison: Wisconsin, 2009. 243-84. Web. 30 Oct. 2014.

Braza, Portia Lei. "warsome." SangyawMindanao. n.p., 8 Feb. 2009. Web. 26 Aug. 2014.

Buendia, Rizal G. "The Mindanao Conflict in the Philippines: Ethno-Religious War or Economic Conflict?" Academia.edu. n.p., n.d. Web. 14 Aug. 2014.

Bulosan, Carlos. America is in the Heart. Seattle: University of Washington, 1973. Print.

--. The Cry and the Dedication. Philadelphia: Temple, 1995. Print.

Busran-Lao, Yasmin. "Human Development, Economic and Social Costs, and Spillovers of Conflict: The Case of the Province of Lanao del Sur." Human Development Network Foundation for the Philippine Human Development Report, 2005. Web. 4 Aug. 2014.

Cabusao, Jeffrey. "Introduction." Kritika Kultura 23 (Aug. 2014): 168-188. Web. 2 July 2015. 
Cagoco-Guian, Rufa. "Gender and Livelihoods among Internally Displaced Persons in Mindanao, Philippines." Brookings-London School of Economics Project on Internal Displacement, 2013. Web. 8 Aug. 2014.

Chow, Christopher. "A Brother Reflects: An Interview with Aurelio Bulosan." Amerasia 6.1 (1979): 155-166. Web. 6 July 2015.

Cotabato Province Government. "History: Overview of its Past, People, and Resources." Cotabato Province, 2013. Web. 29 Oct. 2014.

Fujikane, Candace. "Asian American Critique and Moana Nui 2011: Securing a Future beyond Empires, Militarized Capitalism and APEC." Inter-Asia Cultural Studies 13.2 (2012): 189-210. Web. 15 July 2015.

GPH-MILF. Framework Agreement on the Bangsamoro. United Nations Peacemaker, 15 Oct. 2012. Web. 29 Oct. 2014.

Habana, Pacita. "A Bibliographical Note: Ibrahim A. Jubaira, 1939-1979. Philippine Studies 28. 1 (1980): 98-108. Web. 13 May 2014.

Hagedorn, Jessica. Dogeaters. New York: Penguin, 199o. Print.

Hedman, Eva-Lotta E. "The Philippines: Conflict and Internal Displacement in Mindanao and the Sulu Archipelago." Writenet, 2009. Web. 30 Oct. 2014.

"History of Dole: Gobbling Up Other Monopolies and Expansion to US Colonies and Semi-colonies." Dole Workers Philippines, 10 July 2010. Web. 17 Sept. 2014.

"Infographic: Military Attacks on Lumad Community Schools in Mindanao." Save Our Schools Network, 25 June 2015. Web. 5 July 2015.

Institute of Bangsamoro Studies and the Centre for Humanitarian Dialogue. Armed Violence in Mindanao: Militia and Private Armies. Geneva: Centre for Humanitarian Dialogue, 2011. Web. 14 Aug. 2014.

Jubaira, Ibrahim. "Blue Blood of the Big Astana." The Many Ways of Being Muslim. Ed. Coeli Barry. Pasig City: Anvil, 2008. 3-14. Print.

Jubaira, Ibrahim. "Father's Control." Readings and Communication Skills in English. Avelina C. Grape, Ma. Fe R. Bote, and Ma. Victoria Concepcion L. Lamug. Quezon City: Rex Book Store, 1994. Web. 30 Sept. 2014. 
Kadtuntaya Foundation, Mediator's Network for Sustainable Peace, and the Local Governance Support Program in ARMM (LGSPA). Land Tenure Stories in Central Mindanao. Davao City, Cotabato City, Quezon City: LGSPA, KFI, MedNet, 2009. Web. 8 Sept. 2014.

Kawashima, Midori. “The Islamic Reform Movement at Lanao in the Philippines during the 1930s: The Founding of the Kamilol Islam Society." The Journal of Sophia Asian Studies 27 (2009): 135-159. Web. 8 July 2015.

Lacorte, Germelina. “Tribes Want Lands Out of Bangsamoro." Inquirer.net, 30 June 2014. Web. 15 July 2015.

"Laisa Masuhud Alamia." Muslim Women Past and Present. Women's Islamic Initiative in Spirituality and Equality, n.d. Web. 28 Oct. 2014.

Lao, Loren Hallilah I. “12 More Myths About Islam." Sunday Inquirer Magazine. Inquirer. net, 16 March 2008. Web. 4 Sept. 2014.

--. "Are Muslim Moro Women going CEDAW?" Organized Women go CEDAW: CEDAW Training and Advocacy among Women NGOs and Civil Society Organizations. Ed. Clarissa V. Militante. United Nations Development Fund for Women, 2009. Web. 4 Sept. 2014.

--. “The Debutante is a Muslim Princess." Sunday Inquirer Magazine. Inquirer.net, 21 Sept. 2008. Web. 28 Oct. 2014.

--. “This Ali Fights for Muslim Women.” NewsBlaze. NewsBlaze.com, 18 Nov. 2008. Web. 28 Oct. 2014.

--.. "The Trip to a Forbidden Land." The Many Ways of Being Muslim. Ed. Coeli Barry. Pasig City: Anvil, 2008. 150-159. Print.

---. "Unveiling the Law." Sunday Inquirer Magazine. Inquirer.net, 18 Jan. 20o9. Web. 28 Oct. 2014.

Libretti, Tim. "Beyond the Innocence of Globalization: The Abiding Necessity of Carlos Bulosan's Anti-Imperialist Imagination." Kritika Kultura 23 (Aug. 2014): 236-254. Web. 2 July 2015. 
Lingga, Abhoud Syed M. "Understanding Bangsamoro Right to Self-Determination." Cotabato City: Institute of Bangsamoro Studies, 2008. Web. 13 Aug. 2014.

Lloyd, David, and Laura Pulido. "On Israeli and U.S. Colonialisms." American Quarterly 62.5 (December 2010): 795-809. Web. 7 July 2015.

"Loren Hallilah I. Lao." Muslim Women Past and Present. Women's Islamic Initiative in Spirituality and Equality, n.d. Web. 28 Oct. 2014.

Macasalong, Marjanie Salic. The Liberation Movements in Muslim Mindanao: Root Causes and Prospects for Peace. Diss. International Islamic University, Malaysia, 2013. Web. 13 Aug. 2014.

Matuan, Moctar I. "Inventory of Existing Rido in Lanao del Sur (1994-2004)." Rido: Clan Feuding and Conflict Management in Mindanao. Manila: Asia Foundation, 2007. Web. 6 August 2014.

Midori, Kawashima. "Commentary on a Maranao Petition: Letter of Haji Bogabong, 1934." Journal of Sophia Asian Studies 2o (2002): 211-228. Web. 28 Oct. 2014.

--. "Transformations of Concepts of Homeland and People among the Philippine Muslims: The Bangsa Moro Revolution and Reformist Ulama in Lanao." Bangsa and Umma: Development of People-grouping Concepts in Islamized Southeast Asia. Eds. Yamamoto Hiroyuki, Anthony Miller, Kawashima Midori, and Arai Kazuhiro. Kyoto: Kyoto, 2011. 183-210. Print.

Montiel, Cristina J., Rudy B. Rodil, and Judith M. de Guzman. "The Moro Struggle and the Challenge to Peace-building in Mindanao, Southern Philippines." Handbook of Ethnic Conflict: International Perspectives. Eds. Dan Landis and Rosita D. Albert. New York: Springer, 2012. 71-89. Web. 29 Oct. 2014.

NAFCON. "U.S. Filipinos Join Call for Aquino's Accountability in Mamasapano Fiasco." National Alliance for Filipino Concerns, 12 Feb. 2015. Web. 6 July 2015.

Paredes, Oona. "Indigenous vs. native: negotiating the place of Lumads in the Bangsamoro Homeland." Asian Ethnicity 16.2 (2015): 166-185. Print.

The People of the Philippine Islands v Datu Tahil and Datu Tarson. G.R. No. L-28166. Supreme Court of the Philippines. 2 Nov. 1928. The LAWPHiL Project, n.d. Web. 8 July 2015 . 
Philippine Statistics Authority. "Regional Profile: Autonomous Region of Muslim Mindanao." Philippine Statistics Authority, n.d. Web. 21 Aug. 2014.

Philippine Statistics Authority. "Regional Profile: SOCCSKSARGEN." Philippine Statistics Authority, n.d. Web. 21 Aug. 2014.

Philippine Statistics Authority. "Cotabato City: Total Population by Province, city, Municipality and Barangay: as of May 1, 2010." Philippine Statistics Authority, n.d. Web. 20 Aug. 2014.

Quitoriano, Eddie. “Impact of Oxfam's Aid to Uprooted Peoples' Programme in Central Mindanao.” Oxfam-GB, Sep. 2003. Web. 15 July 2015.

--. "Land, Foreign Aid and the Rural Poor in Mindanao." Focus on the Global South, Sept. 2009. Web. 13 July 2015.

Remollino, Alexander Martin. "Songs of Resistance, Tales of Pride in Moroland." The Moro Reader: History and Contemporary Struggles of the Bangsamoro People. Ed. Bobby Tuazon. Quezon City: CenPEG Books, 2008. 175-9. Kalinaw.org. Web. 7 Sept. 2014.

Rivera, Temario C. "The Struggle of the Muslim People in the Southern Philippines: Independence or Autonomy?" The Moro Reader: History and Contemporary Struggles of the Bangsamoro People. Ed. Bobby Tuazon. Quezon City: CenPEG Books, 2008. 38-55. Kalinaw.org. Web. 7 Sept. 2014.

Rodil, Rudy. "Indigenous Peoples (Lumad) in Mindanao-Sulu Affected by the GPHMILF Peace Process." Asia Peacebuilding Inititives. Asia Peacebuilding Initiative, 4 Nov. 2014. Web. 13 July 2015.

--.. "Magpuyong Malinawon sa Yutang Kabilin (Living in Peace in their Ancestral Domain)." Asian Studies: Journal of Critical Perspectives on Asia 48.1-2 (2012): 47-54. Web. 29 Oct. 2014.

Romero, Paolo. "DepEd to Address Militarization in Schools." Philstar. Philstar Global Corp., 4 Dec. 2014. Web. 5 July 2015.

Salamat, Marya. "Indigenous Peoples' Groups Decry Use of IPRA and NCIP for Development Aggression." Bulatlat. Bulatlat.com, 12 Aug. 2011. Web. 15 July 2015. 
Salman, Michael. The Embarrassment of Slavery: Controversies over Bondage and Nationalim in the American Colonial Philippines. Berkeley: UC, 2003. Print.

San Juan, Jr., E. "Excavating the Bulosan Ruins: What is at Stake in Re-discovering the Anti-imperialist Writer in the Age of US Global Terrorism?" Kritika Kultura 23 (Aug. 2014): 154-167. Web. 2 July 2015.

Streamas, John. "Organic and Multicultural Ways of Reading Bulosan." Kritika Kultura 23 (Aug. 2014): 210-220. Web. 2 July 2015.

Takaki, Ronald. Strangers from a Different Shore: A History of Asian Americans. New York: Back Bay, 1998. Print.

Torres, Wilfredo Magno III. "Introduction." Rido: Clan Feuding and Conflict Management in Mindanao. Manila: Asia Foundation, 2007. 11-35. Web. 6 August 2014.

United States Census Bureau. "Statistical Abstract of the United States, 1961." Washington: US Government Printing Office, 1961. Web. 30 Oct. 2014.

Viola, Michael, Valerie Francisco, and Amanda Solomon Amorao. "Carlos Bulosan and a Collective Outline for Critical Filipina and Filipino Studies." Kritika Kultura 23 (Aug. 2014): 255-276. Web. 2 July 2015.

Wernstedt, Frederick L., and Paul D. Simkins. "Migrations and the Settlement of Mindanao." The Journal of Asian Studies (pre-1986) 25.1: Nov. 1965. Proquest. Web. 20 Aug. 2014.

"Women and Children Killed in Moro Battle." The New York Times, 11 March 1906. Web. 28 Oct. 2014.

Yabes, Leopoldo, Ed. Philippine Short Stories: 1941-1955. Quezon City: UP, 1981. Print. 